Portland State University

PDXScholar

5-8-1978

\title{
Attitudes of Income Maintenance Line Workers in the State of Oregon About the Causes and Amelioration of Poverty
}

Gene Lamar Stutzman

Portland State University

Follow this and additional works at: https://pdxscholar.library.pdx.edu/open_access_etds

Part of the Economics Commons, and the Social Work Commons

Let us know how access to this document benefits you.

\section{Recommended Citation}

Stutzman, Gene Lamar, "Attitudes of Income Maintenance Line Workers in the State of Oregon About the Causes and Amelioration of Poverty" (1978). Dissertations and Theses. Paper 3410.

https://doi.org/10.15760/etd.5292

This Thesis is brought to you for free and open access. It has been accepted for inclusion in Dissertations and Theses by an authorized administrator of PDXScholar. Please contact us if we can make this document more accessible: pdxscholar@pdx.edu. 
ATTITUDES OF INCOME MAINTENANCE LINE WORKERS IN THE STATE OF OREGON ABOUT THE CAUSES AND AMELIORATION OF POVERTY

by

GENE LAMAR STUTZMAN

A practicum submitted in partial fulfillment of the requirements for the degree of

MASTER Of SOCIAL WORK

Portland State University

1978 
TO THE OFFICE OF GRADUATE STUDIES AND RESEARCH:

Norman L. Wyers, D.S.W. approves the practicum of Gene LaMar Stutzman presented May 8, 1978.

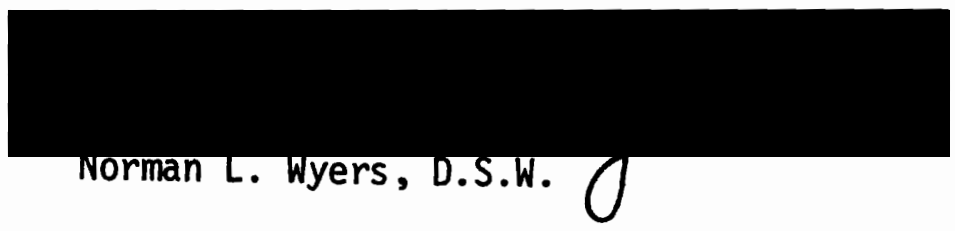




\section{ACKNOWLEDGMENTS}

I wish to thank a number of persons without whose help this study would not have been possible. First of all, I want to thank my advisor and good friend, Dr. Norman L. Wyers for all of his assistance and advice in the form of encouragement, comment, and friendship over the past few years and on this project. I want to thank Dr. Dean Clarkson for his consultation on the statistical analyses of the data. In this regard, a special word of thanks goes to Susan Heins for many hours spent developing a program to analyze the data.

I want to thank the many friends who have encouraged, advised, and otherwise helped me in the course of this study, especially Mary Smucker Lemons who coded much of the data. Finally, to Judy Stutzman for her unending patience, who coded data, proof read the early drafts, and typed the final manuscript--I am deeply indebted. 
TABLE OF CONTENTS

PAGE

ACKNOWLEDGEMENTS ............................ i

LIST OF TABLES .............................. vi

CHAPTER

I INTRODUCTION AND THEORETICAL FRAMEWORK . . . . . . 1

Guiding Hypothesis

Sub-hypotheses

Nul1 Hypotheses

Limitations

II REVIEW OF THE LITERATURE . . . . . . . . . . . 9

Puritanism and the Work Ethic

SSA and SSI

Attitudes of Workers

Advocacy

Background of Line Workers

Prerequisites for Client Advocacy

Benefits: Rights or Privileges?

Urban and Rural Attitudes

II I RESEARCH DESIGN AND METHODOLOGY ..........

The Instrument

Sample Population

Data Collection Methodology

Limitations of the Study

IV RESEARCH FINDINGS ..............

Paradigm I/II as Discriminators of Ideology

Hypotheses

Sample Population

Caseloads, Persons Serviced Per Month, and Job Title

Major Program Area

Educational Background and Educational

Aspirations 
CHAPTER

Representativeness of Sample

Discussion of Findings

Implications of Paradigm I Ideology

Social Work Education

Ideological Differences Between Urban and Rura 1 Line Workers

Feedback From Respondents

Comments on Issues Addressed

Implications for Additional Research

$\checkmark$ SUMMARY AND RECOMMENDATIONS ...........

Purpose

Literature Survey

Summary of Methodology

Limitations of Study

The Survey Instrument

Conclusion

SELECTED BIBLIOGRAPHY .................

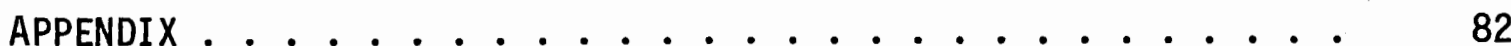

A Questionnaire ................. 82

B Correspondence ................. 91 


\section{LIST OF TABLES}

TABLE

PAGE

I Discriminant Factors in Predicting the Urban-Rural

Response . . . . . . . . . . . . . . . . 40

I Attitudes of Line Workers About Poverty According to

Paradigm I/II Perspectives . . . . . . . . . . .

III Questionnaire Items in Section I Eliciting the Greatest

Amounts of Agreement or Disagreement . . . . . . .

IV Questionnaire Items in Section II Eliciting the Greatest

Amounts of Agreement or Disagreement . . . . . . .

V Questionnaire Items in Section III Eliciting the Greatest

Amounts of Agreement or Disagreement . . . . . . .

VI Size of Worker's Caseload According to Urban and Rural

Classification . . . . . . . . . . . . . .

VII Persons Serviced Per Month According to Urban and Rural

Classification . . . . . . . . . . . .

VIII Major Program Area of Respondent According to Urban and

Rural Classification . . . . . . . . . . . . 54

IX Composite Comparisons of Major Program Areas . . . . . . . 54 


\section{CHAPTER I}

\section{INTRODUCTION AND THEORETICAL FRAMEWORK}

It has been of some interest to the profession of social work that eligible persons underutilize or fail to use social services and benefits to which they are legally entitled. A number of different reasons have been cited in the social work literature and otherwise generally accepted within the ranks of the social work profession as possible or probable causes of underutilization or lack of use. The variety of reasons includes client lack of knowledge about programs, lack of motivation on the part of eligible clients to apply for benefits and services, client unawareness about legal recourse in securing services, and the like. Other reasons are related to the stigmatizing nature of services, including the effects of means testing, particularly in programs such as the food stamp program and public welfare. We have assumed for some time that the means test has an inherently stigmatizing quality--indeed, the means test has long taken the blame for being the main source of stigma in the social services. Bentrup (1964), Titmuss (1968), and others have called for the complete elimination of means testing in relief programs, to be replaced by negative income tax programs, needs tests, and various other methods of determining eligibility and providing services and benefits to poor people in a non-stigmatizing manner.

Outside the growing hew and cry of accusations leveled at the 
assumed stigmatizing nature of means testing, at least two sources offer evidence to the contrary. Gilbert and Specht (1974) conclude:

Distinctions between the means test as an allocative principle and the actual administration of the means test are important considerations. . What is actually at issue in these cases is not so much the principle as the manner in which it is translated into operational procedures. (Italics mine) (Gilbert and Specht, 1974: 65)

This would indicate a large responsibility on the part of the person administering the means test--the line worker, social worker, or the paraprofessional.

Gilbert and Specht base their conclusions in part on the findings of Handler and Hollingsworth (1971). This study was based on a survey of welfare recipients in six Wisconsin counties as to how they felt about different aspects of intake procedures. The findings and conclusions based on the data are enlightening. The authors found that the means test componant of the intake process was not necessarily stigmatizing in and of itself. They note:

If one of our policy reform goals is to make the welfare system less painful to applicants, then these data point to the possibility of a decent intake process. . .

The irreducible minimum of any future means test would involve a fairly routine, not-very-probing inquiry into the applicant's income and resources such as the self declaration system. Contrary to popular belief, inquiry here appears not to be a significant source of irritation. .

The crucial question will be the quality of administration. The Wisconsin data show that intake procedures with a broad substantive reach need not necessarily be very obnoxious to recipients when officials have too much to do, or are not interested in matters other than income and resources. On the other hand, even a simplified means test restricted to income and resources can be vindictively administered by hostile, suspicious officials. (Handler and Hollingsworth, 1971: 87-88)

These findings and conclusions were initially responsible for the 
writer's interest in doing a study of the attitudes of line workers in income maintenance programs. The implication here is that a client may feel stigmatized in any program depending in part on the attitudes of the service provider about the client and his or her situation, i.e., socio-economic background. Nothing the writer had encountered earlier in the literature constituted a study of line worker's attitudes-indeed, the bulk of related literature centered upon client attitudes about welfare and poverty. Thus, the precipitant for this study was an interest in the subject.

Roland Warren, in his article The Sociology of Knowledge and the Problems of the Inner Cities (1971), provides a conceptual framework for this study. Warren delineates two general categories of attitudes about poverty which he terms "Diagnostic Paradigm I" and "Diagnostic Paradigm II." Warren defines the term Diagnostic Paradigm as:

. . that paradigm which carries the explanation for why certain people are poor or disadvantaged, and in so doing implies the way poverty will be conceptulized as a problem, what strategies will be utilized to deal with it, what technologies will be required, and what aspects of the total situation surrounding poverty will be singled out as unimportant or irrelevant. (Warren: 472)

Diagnostic Paradigm I (hereafter Paradigm I) thought identifies poverty as the problem of a dysfunctional individual; an individual who is poor because of weak mental capacity, bad morals, laziness, lack of motivation. Paradigm I thought reflects American ideology--the Puritan ethic of hard work and salvation through work; the idea that anyone can make it if he/she wants to work or if he/she would try harder. An assumption implicit in the ideology is that rights and opportunities are equally available and open to all persons regardless of race, sex, 
or socioeconomic background.

Paradigm I ideology takes a residual view of poverty and poverty programs, which is part and parcel of the Puritan work ethic. The residual perspective maintains that even when the social system is functioning normally, there will still be some individuals who, because of low moral character, laziness, or mental or physical incapacitation, will not be able to make it on their own. Most people can take care of themselves (the idea of rugged individualism), but there will always be those persons who will depend upon public and private philanthropy for their survival. According to Kahn (1973), social welfare history began with this assumption. Public intervention, in the residual view, is seen as a temporary solution for temporary problems such as war, accidents, or depressions which inhibit or prevent the "normal" person from managing on his/her own. The idea important in residualism is that normal people can take care of themselves; thus, people who cannot (those who are poor) are not normal. They are somehow personally to blame for their poverty with little or no blame placed on a dysfunctional social-economic system.

As noted by Warren, Paradigm I ideology has definite implications for practice. "Normal" people can manage on their own when the institutions of society are sound and functioning properly (which is the normal state of affairs). Conversely, public welfare and other income maintenance programs (residual programs) help dysfunctional people (those who are not norma1) who, for one or more of the reasons mentioned above, cannot manage on their own. They must be taught to work, shown how to be properly motivated, taught proper budgeting and 
other self maintenance skills, or be counseled on remedial or moralistic issues. That clients are not to be trusted, that they will try to cheat the welfare system (and it is assumed that many are cheating the system), is a popularly held belief in the public ideology about poor people. It thus follows that the person applying for benefits is apt to be viewed as guilty until proven innocent. Once eligibility is established and benefits given, eligibility checks are continued on a periodic, if not ongoing, basis.

Diagnostic Paradigm II (hereafter Paradigm II) ideology sees poverty as being caused by a dysfunctional social structure. Opportunities are not available to everyone on an equal basis; rather, persons are disadvantaged because of race, sex, or socioeconomic background. The poor are not as likely to have the best educational resources (schools and teachers) available in their neighborhoods as the economically more affluent; women are more likely to be hired for lower status jobs at lower pay than their male equals; racial and cultural minority groups are more likely to represent relatively higher percentages of poverty in their groups because of discriminate hiring and firing practices, poor educational backgrounds due to inferior schools, low status and low paying jobs.

A Paradigm I ideology can be seen as a "victim blaming" (Ryan, 1971) ideology in terms of Paradigm II thought. Victim blaming is the idea that the victims of the dysfunctional social system, the poor and oppressed, are responsible for their poverty and are consequently blamed for it.

The Paradigm II perspective supports the institutional view of 
social welfare. Kahn notes that the institutional view "gives support to the concept that some social services might be regarded as 'public social utilities"" (Kahn, 1973: 77). The assumption of the institutional perspective is that all persons regardless of socioeconomic status need certain services and benefits in the course of daily life. These benefits may range from job counseling to psychiatric therapy; from day care services to income maintenance benefits (now provided by public welfare, food stamps, and the like) and health and medical services. Persons applying for benefits are seen not as patients or cases, but citizens. Benefits are provided on the basis of citizenship as being the criterion for eligibility.

Although Paradigm I and Paradigm II have been broken down into subcategories (See Hussmann, 1976 and Dominick, 1977), for the purposes of this study, the writer will concentrate on the general differentiation between Paradigm I and Paradigm II in analyzing the attitudes and ideologies of line workers in the Adult and Family Services (AFS-previously Public Welfare), Food Stamp, Social Security Administration (SSA), and Supplemental Security Income (SSI) programs.

The main analysis of this study will be to determine if Warren's Paradigm I-Paradigm II conceptual model will differentiate ideologies of line workers in these programs. The writer is also interested in analyzing the attitudes of workers to determine if there are significant differences in attitudes based on an urban/rural distinction, i.e., whether the agency is in an urban or rural setting (Urban and Rural will be defined in terms of SMSA guidelines outlined in Chapter III). Thus, the Hypotheses and Nu11 Hypotheses are as follows: 
Guiding Hypothesis

There are identifiable differences in the attitudes and ideology of urban and rural income maintenance line workers about the causes of poverty, programs to fight poverty, and their role as workers in working with poor people.

\section{Sub-Hypotheses}

I-A Diagnostic Paradigm I and Diagnostic Paradigm II will differentiate ideologies of line workers about the causes of poverty, programs to fight poverty, and their role as workers in working with poor people.

I-B There are identifiable attitudinal and ideological differences between income maintenance line workers based on an urban-rural comparison.

\section{Nu11 Hypotheses}

i-a Diagnostic Paradigm I and Diagnostic Paradigm II will not differentiate ideologies.

$i-b$ There will be no differences in the attitudes and ideologies of income maintenance line workers about the causes of poverty, programs to fight poverty, and their role as workers in working with poor people, based on an urban-rural comparison.

\section{Limitations}

At this point a short discussion about the limitations of this study is in order, in terms of logistics as they affect an examination of other important variables. Data on other variables were collected. They include sex, age, level of education, where educated, when educated, professional major, years working with poor people, years in 
present position, parent's occupations and educational levels, size of caseload, number of persons serviced per month, and future educational aspirations. These data will be presented and examined only in terms of the urban/rural relationship (for example, the numbers of persons with social science degrees working in rural agencies compared to those working in urban agencies) and are included in the interest of complete presentation and potential future research concentrating on these variables. A complete statistical examination of these variables is beyond the scope of this study. 


\section{CHAPTER II}

\section{REVIEW OF THE LITERATURE}

Much has been written about poverty from both philosophical and theoretical viewpoints, and much research has been done. Attitudes of the poor about work, status, money, morals, living standards, antipoverty programs, and poverty in general have been measured repeatedly to gain some insight about possible causes of poverty. Attitudes of the non-poor about the causes of poverty, poor people in general, antipoverty programs, and the "welfare system" in general have also been examined in order to demarcate possible poor/non-poor ideological differences, again to gain some understanding about the causes of poverty and some ideas about ways to eradicate poverty. In recent years, some research has been done to measure the attitudes of professional social workers (those workers with MSW degrees or higher) about the causes of poverty, poor people, professional ideology, ideology of the poor, and ideas about working with poor people. Research in this category tends to focus on comparisons of professional and national ideology and attitudinal differences between professional and non-professional workers in social services such as mental health and other therapeutic/ counseling oriented settings. It is interesting that little research has been done to measure attitudes and ideology of line workers (especially those of non-professional workers) in the areas of public welfare (AFS), food stamps, social security (SSA), and supplemental 
security (SSI) relating to the causes of poverty, the eradication of poverty, and working with poor people. This needed area of research seems to reflect a gap in the current literature and is the main thrust of this study.

Certain of the following studies, and publications cited and otherwise alluded to, do not deal directly with this study content but are clearly related in terms of ideology. A search of the literature has revealed few studies directly related to this study, and no single study dealing with the same population and question content areas has been found. Certain studies directly address, or allude to, differences in attitudes of certain groups based on an urban-rural comparison, but none have examined the attitudes of line workers in income maintenance programs on an urban-rural basis.

\section{Puritanism and the Work Ethic}

Current literature would indicate that attitudes about poverty and welfare programs, in the main, reflect the ideology of Puritanism and the work ethic. This ideology results in what William Ryan (1971), in his now classic book, terms "blaming the victim." Blaming the victim reflects a strong Paradigm I ideology. The Puritan work ethic ideology says that any person can make it in this society if that person is motivated and realty tries. Conversely, anyone who is poor is poor because he/she is lazy, unmotivated, or otherwise unable to take care of himself/herself because of individual problems or shortcomings. Although much poverty may be caused by external forces beyond the individual's control (high unemployment, underemployment, disadvantages in the job market due to sex, race, or other socioeconomic factors), 
in Ryan's terms, the poor person is blamed for his/her own poverty--we blame the person who may be a victim of forces beyond his/her control. This victim blaming phenomenon is manifest in our social attitudes about public welfare and related income transfer programs and within the programs themselves. James (1972), Grosser (1973), Leonard (1975), and Galper (1975) have each written about the direct and indirect impact of Freudian psychology on the, profession of social work in terms of victim blaming. James points out that in concentrating heavily on Freudianism, the social work profession supports victim blaming by perpetuating the ideology of individualism. By concentrating on individual change and growth, the greater part of the profession ignores important external forces which may be at the root of individual problems (James, 1972: 95-96). Grosser approaches the subject of individualism in terms of the residual view of poverty discussed in Chapter I. The author notes that social work has historically reflected this residual view of poverty, and the resulting modes of social work practice have been "directed at helping individuals, through therapy, education, counseling, and other restorative and rehabilitative techniques, to overcome their inadequacies and achieve a modicum of social equity" (Grosser, 1973: 10). Galper (1975) presents an extensive essay on individualism and social services from a political perspective. He concludes that the social welfare system has historically supported the capitalist system and the ideology of individualism and, further, that Freudian thought (particularly in his essay Civilization and Its Discontents) supports this ideology by focusing on the individual. The individual in this context is active in pursuing his/her own personal agenda, and the 
only actions taken by the individual will be those which further self interest. The end result of this view is a welfare system based on a distrust of human nature. Leonard concludes that the role of social work in the capitalist system "has been to identify, respond to, and control the individual casualties of the economic structure and of the material, physical and emotional pressures which living in a competitive society produces" (Leonard, 1975: 49).

In a study of 375 residents in the Greater Boston area, Williamson (1974) noted that liberalism and the work ethic are the two greatest predictors of opposition to increased welfare benefits. Beliefs about the work motivation of the poor were highly correlated with the work ethic ideology. Little variation in belief was found by education and income, but when such variance was found, it was generally those with the most income and the highest education who held the "least antiwelfare beliefs," and those with the lowest income and least education who held the "most anti-welfare beliefs." Williamson concludes:

On such issues as idleness, dishonesty, and fertility there is evidence that misconceptions about the welfare poor exist at a11 socioeconomic levels and that these misconceptions are consistantly in the anti-welfare direction; however there is only a weak relationship between such beliefs and opposition to increases in welfare benefits. Beliefs about the motivation of the poor and such ideological predictors as selfreported liberalism and work ethic account for more variance in/or opposition to increased welfare benefits than do social class factual beliefs." (Williamson, January, 1974)

These data support the earlier research findings of Alston and Dean (1972), which indicate that in most cases higher education was not associated with more liberal attitudes. Also, ideological reactions to poverty are the partial results of Puritan and social Darwinian (survival of the fittest) influences on American values. The authors 
note that "a third of the population defined poverty as due to a person's lack of effort" (Alston and Dean, 1972: 22). The observation is also made that these ideologically based and broadly held values may influence the delivery of transfer payments (AFS benefits, food stamps, and SSA/SSI benefits) in the social services:

These data suggest that a relatively large minority define the poor in negative terms, define some or most welfare recipients as dishonest, and reject possible increases in welfare costs. These negative correlations place a heavy burden on welfare personnel, as they are expected to carry out policies not completely accepted by the general public. (Alston and Dean, Ibid: 22)

Osgood (1977) collected data in a 1974 statewide sample survey in Pennsylvania to determine if there were differences in people's attitudes toward welfare based on an urban-rural comparison. A total of 1,426 responses were received to questions dealing with topics such as whether welfare recipients wanted to work, the role of the federal government in welfare programs, and the provision of a guaranteed annual income. Osgood found that rural residents were less likely than residents of highly urban areas to support welfare programs or be sympathetic to welfare recipients. Rural respondents were less likely to trust the honesty of recipients and doubted to a greater degree the willingness of recipients to work. Also, a larger percentage of rural respondents disagreed with the idea that government should be responsible for providing jobs for everyone. The author concludes:

Taken as a group these responses indicate that a residual view of welfare prevails in rural areas of Pennsylvania. The poor individual is distrusted and is held responsible for being poor. Rather than viewing poverty as the result of widespread unemployment and other structural inefficiencies in society, almost half of the respondents in rural and less urbanized areas felt that welfare recipients were not even willing to work. (Osgood, 1977: 46) 
In a nationwide survey taken in December, 1965, the question was asked, "In your opinion, which is more to blame if a person is poor-lack of effort on his part, or circumstances beyond his control?" Twenty-nine percent of the respondents blamed poverty on circumstances beyond control. Forty percent of the respondents said that poverty was a result of an individual lack of effort, and only twenty-eight percent believed the cause of poverty was a combination of both lack of effort and extenuating circumstances (Schiltz, 1970).

A Harris poll taken in 1964 indicated that a full sixty-eight percent of respondents agreed that government must be responsible for the poor, while at the same time, sixty-four percent believed that welfare and relief programs make people lazy (As cited by Schiltz, 1970).

These results seem contradictory and may reflect the double message line workers in social service programs receive. First, a strong minority believe poverty is the fault of the individual (Paradigm I), and an additional third believe the individual is at least partially responsible for his/her own poverty (also Paradigm I). Nearly equal percentages believe government should take care of poor people but that government programs have a negative effect (cause laziness and dependency). The line worker, given two distinct messages, is caught in the middle.

Twelve newly graduated MSW social workers in a public welfare setting in California were observed over a two year period beginning in June, 1966. Eleven of the twelve were assigned as child welfare workers in the agency's foster care program, and the twelfth was 
assigned to the agency's protective services unit for non-financially aided client population, i.e., those clients not financially dependent upon the Department. It was noted that employment in public welfare departments undermined professionalism due to heavy caseloads, many emergencies, lack of privacy, constraints on decision making, and the like, causing the workers to become disillusioned. The author writes:

Based on his observations, the author concludes that the two principal feel ings expressed by the new professional social workers during the two year period were frustration and fatigue. They felt frustrated by natural constraints that did not permit them to employ the values, knowledge, and skills that their training had prepared them to use. They were exhausted by having day after day to face critical human situations with insufficient materials, intel lectual and emotional resources, and support. (Wassermann, 1970: 99)

This study seems to describe most clearly the reality the doublebind situation imposed on line workers, especially in agency settings dealing with financial aid benefits.

Beliefs about the poor make a great deal of difference in the ways society chooses to deal with the poor. Such beliefs about the causes of poverty and the poor in general are directly related to basic ideology. In his 1974 survey of 300 women in Boston, Williamson studied the impact of ideology on beliefs about the causes and eradication of poverty. The author notes that to garner support for better programs and increased benefits for the poor, beliefs about the poor and the causes of poverty must first be changed. How are these beliefs to be changed? The author concludes:

Those who are looking for ways to change popularly held subjective beliefs about the poor may do well to consider possible sources of change in support for the work ethic and other dimensions of general ideological orientation. (Williamson, June, 1974: 646) 
$\underline{\text { SSA and SSI }}$

Few studies have been done relating directly to public attitudes about social security programs and line worker's attitudes toward recipients of social security. In his book Public Attitudes Toward Social Security, 1935-1965, Schiltz (1970) makes reference to "some dissatisfaction" (in terms of the general public) with the new social security program in the decade of the 1930's and examines patterns of program use through 1965.

In 1972, by enactment of federal legislation, Supplemental Security Income (SSI) replaced the old state-administered programs (01d Age Assistance, Aid to the Blind, and Aid to the Permanently and Totally Disabled) and was assigned to the Social Security Administration. Local SSA offices were given responsibility for administration of SSI when the legislation went into operation in January, 1974. According to Weaver (1977), "There have been bitter complaints about the sometimes cool and seemingly unfeeling treatment given applicants and beneficiaries in the district offices of SSA, which administers the program in local communities." Weaver also notes the absence of linkages and referral procedures between SSI beneficiaries and other social services. Although the "failure of states and SSA to develop linkage and referral procedures" may be partially to blame for a lack of service continuity for clients, worker attitudes about SSI and recipients may also be responsible.

Parker (1976) cites some problem areas at the inception of the SSI program. Social security, in the main, has always been seen as an "efficient" agency with a "clean" image. The SSI programs have not 
been viewed in such a light. Parker adds:

The public image of the focal organization (SSA) at this point, was an outstanding characteristic, and very important to maintain. Therefore, from the beginning, the SSI program was differentiated from insurance programs administered by the Social Security Administration. This differentiation can be seen as the Social Security Administration's way of keeping separate "earned" from "relief" income. If this was (and is) the case, it seems pointless to hope the SSI program would benefit from the "clean" image of the SSA when the administration itself did not accept SSI as an equal to OASDI. (Parker, 1976: 32-33)

Parker points out particular problems with staff since SSI has become operational. Problems include lack of training regarding new procedures and forms, while staff are still evaluated according to old "criteria of efficiency and effectiveness that were used with more traditional, non-welfare-like clients of social security," and staff are over burdened and largely uninformed (Parker, Ibid: 34). The author concludes that there are no differences in funding, although in practice the "Social Security Administration has distinguished emphatically between OASDI payments and SSI payments right down to the color of checks, both OASDI and SSI transfers from workers to non-workers" (Parker, Ibid: 35 ). The end result is that the public and the Social Security Administration (and finally line workers in the offices) perceive the sources as different. Translated to worker attitudes, "SSI recipients are always suspect--eligibility must be proved, while OASDI recipients are innocent until shown guilty of cheating" (Williams, 1973: 13, as cited by Parker, Ibid).

\section{Attitudes of Workers}

There have been a number of studies done which examine and compare attitudes of line workers in terms of professional rank and program 
differences (social services, financial services, and the like). Grosser (1965) found that agency staff tended to be more pessimistic in their views about the local community than were residents. Staff felt that the community was a worse place to live, its schools were poorer, and the life chances of its people more hopeless than did the residents themselves. Indigenous staff members appeared to be significantly more accurate in assessing community views than were their professional colleagues.

The findings of Patino (1972) support those of Grosser. This survey compared the attitudes of professional and paraprofessional workers in selected California State Service Centers toward various facets of their work, their perceptions of the consumer's perception in life, and toward people in general. Professionals placed significantly lower in their "trustworthiness" and "faith" in their clients and in other people in general.

Greenstein (1975) examined opinions of three samples of welfare workers--financial eligibility, non-MSW service, and MSW workers--about selected welfare issues. On the basis of the data, workers were classified along a continuum of "client centeredness." Two patterns clearly emerged in this study. The first pattern was linked to the MSW sample. These respondents were found to be the most client centered, characterized by positive opinions toward program recipients and support for broad service-oriented welfare programs. The other consistent pattern found in this study was linked to the financial eligibility sample. These respondents were found to be the least client centered and were characterized by negative stereotypes of 
recipients and restrictive views about welfare programs. The non-MSW respondents fell between these two groups and showed a degree of client centeredness.

These findings, at first glance, appear to disagree with those of Grosser and Patino. These differences may reflect different levels or dimensions of analyses in the studies. Respondents in the MSW sample (Greenstein) may be highly client centered but still share the same ideology of respondents in the studies of Grosser and Patino. At the analyses level, Grosser and Patino are both measuring attitudes of workers about the community and people in general and clients' perceptions--Greenstein is measuring the degree of client centeredness which is not measured or examined in the other studies. It should also be noted that positive or negative attitudes about clients may be a function of program differences--for example, social security and public welfare programs both deal with financial eligibility but attitudes of workers about clients in the social security programs may be very different from attitudes of workers in the public welfare programs about their clients.

\section{Advocacy}

Epstein (1968) contrasted attitudes about social action strategies (client advocacy) of welfare workers and housing reform workers. Respondents in this study were MSW's representing workers in financial eligibility and in social service programs and provide an interesting comparison of attitudes at yet a different level. Eight-five percent of the respondents approved of encouraging low income people to file complaints through official agencies, and seventy percent approved of 
professional groups endorsing political parties and campaigns which favored proposed reform. By contrast, considerable dissension was found among respondents over strategies involving non-institutionalized conflict. Approximately one half of the social workers rejected the idea of the profession's supporting the efforts of protest groups when they ask for social work support. Larger percentages rejected the notion that social workers should actively organize such protestations (sixty-three percent in housing reform and seventy-one percent in welfare). In a second battery of items, Epstein asked respondents to choose the most effective strategy for (1) professional social workers, (2) civic minded, middle income people, and (3) low income people acting in their own behalf. Questions were intended to invoke an image of the social action roles social workers project for themselves as well as for other class groupings. From the data, a general tendency is seen to perceive those strategies defined as most legitimate to be most effective for social workers--seventy-five percent chose consensus strategies in welfare reform. Epstein concludes that social workers tend to regard traditional professional modes of participation as most effective for themselves, especially in areas in which they have vested interests.

Clark (1964), in her study of 167 members of the Eastern Massachusetts Chapter of NASW, reports findings which are similar to those of Epstein. The most favored social action strategy of respondents in Clark's study was expert testimony in the form of "statements on issues by professional social work organizations," and the least favored strategy was "direct action, either by the individuals or official social work groups" (Clark: 28). 
These studies cited reflect an ideology among workers which supports status quo conflict--those forms of conflict which are socially acceptable by the greater society. These attitudes are indicative of a basic Paradigm I ideology.

\section{Background of Line Workers}

The attitudes of 2,000 professional social workers about change targets, goals, and tactics were studied by Arangio (1970). A questionnaire utilizing a forty-five item Likert scale was administered. Items had to do with "change targets, goals, and tactics" representing either an "individual change" or "social change" orientation. Arangio found that most social workers were "strongly oriented toward individual change," and most disagreed with tactics of a controversial nature, i.e., social change as opposed to individual change.

In separate studies based on Roland Warren's conceptual model, Hussmann (1976) and Dominick (1977) have broken down the hypothesized categories (Paradigm I/II) into sub-categories. These sub-categories are: Paradigm I-conservative, Paradigm I-liberal, Paradigm II-liberal, and Paradigm II-radical. In abbreviated terms, a Paradigm I-conservative philosophy would say that the individual is responsible for his/her own poverty--change must come from the individual. A Paradigm I-liberal philosophy says that poverty is the fault of the individual but that some change should come from institutions within society. A Paradigm II-liberal analysis says that poverty is the fault of dysfunctions in the socioeconomic system but that individuals must change to function better under the system. A Paradigm II-radical philosophy says that poverty is caused by dysfunctions in the socioeconomic system and 
that the system is in need of radical change. Hussmann (1976) measured the attitudes of sixty-four social workers in a selected sample. The social workers' responses in this sample were predominantly in the two middle liberal categories (Paradigm I-liberal and Paradigm II-liberal). Hussmann writes, "They (social workers) would not tend to blame poor clients directly for their poverty but would still place ultimate responsibility on their shoulders" (Hussmann: 57). In terms of the number of years of experience as a factor in shaping attitudes, Hussmann found that direct service respondents with more experience (more than nine years in the field) tended to be slightly more conservative in their responses than those with less experience (less than nine years).

Dominick, Swartz, and Taylor (1977), using Warren's model in their analysis of the attitudes of 101 line workers in juvenile delinquency programs, reported findings similar to those of Hussmann. Dominick, et al, found that the analysis validated the hypothesized categories of the model. Their sample of line workers tended to strongly agree with the two liberal categories. There was also agreement with some significant statements which emphasized dysfunctions in organizations as causes of delinquency. The worker, it was emphasized, should work with organizations and do family therapy to reduce the incidences of juvenile delinquency. Overall, there was disagreement with statements emphasizing the present social structure as causative of delinquency. Dominick concludes that overall, there appears to be an emphas is on the situation centered Paradigm I approach but there was a trend towards agreement with some Paradigm II-1iberal statements, but a reluctance among sample respondents to look at broad institutional factors or to 
work towards change.

Grimm and Orten (1973) studied attitudes of 117 social work students about the poor. Factor analyses were done on socioeconomic variables such as age, sex, marital status, socioeconomic background, father's education, work experience, etc., to determine if these factors significantly affected student's attitudes about the poor. Grimm and Orten found that age showed some difference (students under age twentyfive showed a higher percentage of positive attitudes about the poor than those over twenty-five) while sex of respondents showed no significant difference in attitude. A fairly strong predictor was the marriage-parenthood factor. Data showed that as family responsibilities increased, students displayed more negative attitudes about the poor. Another category was socioeconomic background. Findings indicated that students from lower socioeconomic backgrounds tended to be less sympathetic to the poor. Father's education (which may correlate directly with the socioeconomic variable) was found to be a contributing factor. Students whose fathers had at least a high school education or who were in high status occupations had more positive attitudes about the poor, i.e., more sympathetic interpretations of poor people's problems were associated with higher education or occupational status. Pre-graduate school experience associated with positive identification with poor people were (1) an undergraduate major in sociology or social work; (2) a degree from a public university or a school not in the southeastern United States; and (3) little or no previous work experience in fields other than social work. A last major variable had to do with experience in a public welfare agency. Fifty-nine percent of those 
respondents who had no experience working in public welfare had positive attitudes, fifty-six percent who had two years experience or less working in public welfare had positive attitudes, and of those with three years or more experience, twenty-six percent displayed positive attitudes about poor people. These findings relating attitudes to length of work experience seem to support the findings of Hussmann (1976), although populations, professional status, and agency settings are different in the two studies. It may be instructive in future studies of this nature to compare and contrast attitudes of line workers of different professional status (students, MSW workers, and non-MSW workers) in various agency settings (public welfare, private social service agencies) and with varying degrees of work experience.

\section{Prerequisites for Client Advocacy}

What then are the prerequisites for client advocacy in the social services, given the pressures of ideology (the Protestant work ethic), job pressures, professional peer pressures, and organizational constraints? Where does one, hoping to affect change in the social services in terms of advocacy at the line worker level, begin to work on change goals? In his study exploring the effects of organizational rank, specialization, and professionalization on social worker's approval of radical strategies of social change, Epstein (1971) provides us with a clue. He points out that on the measure of conflict approval in public welfare, line workers are as likely as executives to approve of conflict strategies in this issue area. If executives and administrators approve of radicalism, line workers will, in most cases, also approve. Line workers are not likely to approve of 
radicalism if their superiors disapprove.

Armitage (1974) discusses the impact of rank and promotion on the attitudes of line workers in the social services:

Contact with clients is limited to the lower ranking personnel of the organization who are least able to produce change in policy. Furthermore, organizational policy in effect, if not by intent, tends to discourage sensitivity to the client. Promotion, for example, means that the social worker takes a step away from the client and a step deeper into the organization. The best candidate for such a promotion will be the worker who is interested in the organization rather than in the client. Hence, the promotion structure discourages client-centeredness, and this in turn discourages the workers from articulating client-centered interests. (Armitage, 1974: 307)

The studies of Patti (1974) and Hoshino (1971) support those findings of Armitage and Epstein, but add some important dimensions and conclusions. Patti outlines the following requirements needed to sustain internal advocacy in the social services: organizational legitimacy (from administration), professional credibility, and support of colleagues. According to Patti, fear of dismissal and a limited chance for advancement in the organization are the two greatest impediments to advocacy at the line worker level.

Hoshino lists three prerequisites which he considers necessary before client advocacy can be a viable element of the public welfare worker's role: (1) a common population made up of individuals who are cognizant of their rights and are willing to take the risks involved in defending their rights and pushing their claims; (2) a climate of administration that accepts and supports the principle of client advocacy; and, (3) a recognition that the public welfare function includes both adversary and service elements. 
Benefits: Rights Or Privileges?

A basic notion in these prerequisites is the assumption that a client population that views benefits as rights rather than as privileges is an integral componant in a client oriented social service system. Kahn (1973) discusses the nature of social service rights in terms of public welfare, public education, and social security benefits Questions of rights and privileges are philosophical ones but have very definite consequences in practical application. The difference here is that privileges cannot be demanded or guaranteed--rights can be demanded by the claimant in a court of law. Social security benefits are seen as a right in this country. Employees pay into social security and, in return, receive certain specified benefits as a right of citizenship. Kahn notes: "Such right is the reciprocal of concomitantly specified obligations" (Kahn: 84-88). Public welfare benefits are a legal right in the United States, but because of the nature of the prevailing ideology (the Protestant work ethic) are treated in most sectors as privileges. Whether particular benefits are considered rights or privileges, may make a great deal of difference in terms of how clients feel about them, how benefits are delivered, and how the general public feels about benefits and those who receive them.

A direct result of services and benefits which are given as privileges, in a stigmatizing manner, or against prevailing ideology and desire of society, is that people in need often fail to receive services and benefits, and programs are underutilized. The poor are often blamed for failing to use services (another example of blaming the victim). Gartner (1970) expands on some reasons for under- 
utilization or non-utilization:

If as these data show, the poor will utilize services delivered in their community, by persons they know and trust, in a manner respectful of them and useful to them, then perhaps it is time to stop asserting that it is the poor who fail to utilize the services, but rather to recognize that it is the professional, quick to categorize and stereotype the poor, who must change their attitudes. Given the need for services and the evidence that when they are hospitably offered and well delivered the poor utilize them, it may be fair to state that programs not faced with a strong demand may be either offering an irrelevant service or failing to organize the service in the most effective manner. (Gartner, 1970: 71-72)

\section{Urban and Rural Attitudes}

Little has been done short of speculation dealing with attitudes of line workers about poverty, clients, or programs in general on an urban-rural basis. Osgood (1977) alludes to possible differences in service delivery between rural and urban line workers in that "case by case practices may tend to be more restrictive in rural areas than in urban areas."

Urban-rural comparisons of attitudes of residents (Summers, 1969, Goudy, 1970, and Wooster, 1972) and attitudes of social science teachers (Roark, 1973) have all concluded that respective respondents from rural areas tend to be less sympathetic to the poor and display attitudes more residual in nature.

Goodwin (1973) stresses the need for research into the perceptions and attitudes of workers in social service programs:

Middle class persons who hope to help the poor, such as counselors or trainers, are unlikely to do so if they misperceive the orientations of the poor. Most welfare recipients do not need to have their level of aspirations or work ethic raised. . .

- . while research on the orientations of the poor should 
continue, it is necessary to study the perceptions of those who would help the poor. Especially important is study of how perceptions change--for example, what kinds of events alter the orientations staff hold about trainees--and the relation between accuracy of perception and effectiveness of program action. (Goodwin, 1973: 564) (Italics mine)

Hopefully, the data from this study will be of some value in developing an understanding of the attitudes, perceptions, and the orientations of line workers, particularly on the basis of an urbanrural comparison. 
CHAPTER · III

RESEARCH DESIGN AND METHODOLOGY

\section{The Instrument}

A three part, self-administered questionnaire was used to collect the data. In addition to the three parts of the questionnaire were sections containing biographical questions, agency information questions, and questions dealing with the respondent's feelings about his/ her educational background and educational aspirations (see Appendix A).

Twelve statements contained in each of the three sections of the questionnaire were designed to differentiate Paradigm I and Paradigm II. Response to each statement was made in conjunction with a ten point scale ranging from "Very Strong Agreement" or "Very Strong Endorsement" (1) to "No Agreement" or "No Endorsement" (9), with a separate tenth point added for "Undecided." Thus, each statement would be read and responded to individually and an appropriate number indicating the response on the scale to each item entered in a space provided beneath each statement.

The following introductory paragraph proceeded Part I:

Although the above information about you and your role in the agency is important, your personal attitudes and beliefs about poverty and about poor people in general are of equal interest. Of particular importance are your own personal views about the causes of poverty, the types of programs needed to combat it, and the kinds of services which should be offered to poor people.

An additional paragraph describing the use of the attitude scale 
was contained only in Part I. The paragraph reads as follows:

Following is an attitude scale ranging from 1 through 10 . It is intended to measure how the causes of poverty are at least partially explained by the statement. Notice that a 1 means that you feel that all the causes of poverty can be explained by the statement while a 9 means that you feel that no amount of poverty can be explained by the statement. Please also note that you may give a 10 response if you are undecided or don't know for certain how you feel. You may indicate your choice by selecting the appropriate number and placing it just below the question iteself.

Part I of the questionnaire was entitled On the Causes of Poverty. The heading "Amount of Poverty Explained by the Statement" described the scale which ranged from "All Poverty Explained" (9) to "None Explained" (1), and an "Undecided" (10). Twelve statements followed, seven of which were designed to differentiate Paradigm I and five designed to differentiate Paradigm II. Items $1,3,5,6,7,9$, and 12 were defined as Paradigm I statements. Items 2, 4, 8, 10, and 11 were defined as Paradigm II statements. An example of a Paradigm I statement in Part I is item 6:

Many low-income people are without sufficient management or budgeting skills, deficiencies which tend to keep them in poverty.

A response 1 through 5 on the scale would indicate an agreement with the statement (all, much, or some poverty explained). This was defined as a Paradigm I statement because it reflects a belief that poverty is the fault of the individual (a lack of skills make the individual deficient). A 6 through 9 response was simply defined as "mix/other," with a 10 response "undecided" (throughout the questionnaire, any response 6-9 will be defined as "mix/other"--the rationale for this definition is that disagreement with any particular statement does not necessarily indicate the alternate Paradigm ideology). 
An example of a Paradigm II statement in Part I is item 4:

The dynamics of our capitalist economy cause poverty; thus, significant numbers of people end up being poor through no fault of their own.

This is clearly a Paradigm II statement in that agreement (response 1-5) would lay blame on the capitalist economy as the cause of poverty. Again, response 6-9 indicates a "mix/other," with a 10 "undecided."

A flaw in Part I of the questionnaire, due to an oversight, should be pointed out. There are seven Paradigm I statements and five Paradigm II statements in Part I. In Parts II and III, the breakdown is six Paradigm I and six Paradigm II statements in each. This flaw may skew or bias the data in Part I.

Part II of the questionnaire was entitled On Programs to Fight Poverty. The scale heading was "Program Effectiveness" with a range from "Very Strong Endorsement" (1) to "No Endorsement" (9), with 10 "Undecided." Paradigm I statements in Part II were items $2,4,6,7$, 11, and 12. Paradigm II statements were items $1,3,5,8,9$, and 10 . An example of a Paradigm I statement in Part II is item 12:

Work training programs should be integral parts of public assistance programs as a requirement. Job training would provide more motivation for self maintenance.

Endorsement of this statement (1-5) would indicate a belief that people are poor because they are not motivated to take care of themselves and must be taught to work. No responsibility for causing poverty is placed on society or its institutions.

An example of a Paradigm II statement in Part II is item 10:

If every person who wanted to work was guaranteed a job, poverty could be significantly reduced.

Agreement with this statement (1-5) would indicate a belief that society 
is at fault for not providing jobs to people who want to work. It is assumed that many of the poor are people who want to work but do not have, or cannot find, jobs--enough of the poor that poverty could be significantly reduced if jobs were provided.

Part III of the questionnaire is entitled On Working With Poor People. "Effectiveness of Workers" is the heading of the scale which ranges from "Very Strong Endorsement" (1) to "No Endorsement" (9), with 10 "Undecided." Paradigm I statements in Part III include items 1, 4, $6,8,9$, and 11 . Items $2,3,5,7,10$, and 12 were defined as Paradigm II statements. An example of a Paradigm I statement in Part III is item 1:

The principal efforts of workers should be to help poor people gain psychological insights into the causes of their poverty.

A response 1 through 5 would indicate that poverty is caused by personal problems which could be overcome by a psychological understanding of such problems.

Item 3 is an example of a Paradigm II statement in Part III:

Those working with poor people would best help them by involving themselves wholeheartedly in political activities aimed at producing a more equitable society.

Endorsement of this statement (1-5) as a legitimate role for the worker assumes that inequities in society are a cause of poverty and political action would help to alleviate these inequities.

Sample Population

The agencies in this statewide study represented a selected sample of Adult and Family Service agencies (hereafter AFS--previously public welfare) which administer the food stamp programs in most cases, and the 
Social Security Administration, which also administers the Supplemental Security Income program (hereafter SSA and SSI).

Respondents in the AFS offices included Welfare Assistance Workers (WAW) and Social Service Workers. In smaller offices, food stamp eligibility is handled by both WAW and Social Service Workers. In larger offices, line workers are assigned exclusively to the food stamp program. Respondents in SSA/SSI offices included Claims Representatives and Service Representatives. In the more rural offices where one office serves a large geographical area, a Field Representative who works outside the office most of the time also determines eligibility. Therefore Field Representatives were included in this study.

In a11, there were 269 respondents--ninety-nine representing SSA/ SSI and 170 representing AFS/Food Stamps. These differences in representation reflect the size difference between SSA and AFS (in terms of the number of line workers) in Oregon--AFS is a much larger agency employing many more line workers.

Portland was considered the only urban area in the state by Standard Metropolitan Statistical Area (SMSA) guidelines. Forty-six urban respondents representing four Portland SSA/SSI offices accounted for forty-six percent of the SSA/SSI response and forty-five percent of the total urban response. Fifty-six urban respondents representing two Portland AFS offices accounted for thirty-three percent of the total AFS/Food Stamp response and fifty-four percent of the total urban response.

Fifty-two rural respondents representing SSA/SSI offices in Salem, Ontario, Albany, La Grande, Bend, The Dalles, Medford, Pendleton, and 
Klamath Falls accounted for fifty-three percent of the total SSA/SSI response and thirty-one percent of the total rural response. One hundred fourteen respondents representing AFS/Food Stamp offices in Bend, Salem (two offices), Klamath Falls, Pendleton, and Medford accounted for sixty-seven percent of the total AFS/Food Stamp response and sixty-nine percent of the total rural response.

Over al1, 103 (thirty-eight percent) of the 269 respondents represented urban agencies and 166 (sixty-two percent) respondents represented rural agencies.

\section{Data Collection Methodology}

Authorization for line workers to participate in this study was granted to administrators of SSA offices by Lee R. Christenson of the Social Security Administration and to AFS office managers by Linda Kaeser, Executive Director of AFS. Branch managers of AFS offices were sent letters (see Appendix B) describing the study and announcing the interviews. Branch managers of SSA/SSI offices were sent similar letters (see Appendix B). Each agency manager was contacted by telephone within two weeks after the letters were sent and appointments were scheduled for meeting with the staff and administering the questionnaires. In most cases, blocks of time were scheduled by the agency for the interviewer to address all of the staff. Although questionnaires were done individually, the interviewer met with the workers to introduce the study, answer questions, and participate in discussion after questionnaires were completed, if this was desired by interviewees. Questionnaires required between twenty minutes to an hour for completion--one half hour being an overall average. Every attempt was made 
to encourage workers to complete questionnaires. Interviewees were encouraged to add additional comments on the questionnaires. In the case of absences of line workers, the appropriate number of selfaddressed, stamped envelopes and questionnaires was left with supervisors. In most cases, these questionnaires were completed and returned within a two week period.

The overall rate of return on all questionnaires was eighty-four percent. Ten percent refused to complete questionnaires and six percent failed to respond for "other" reasons. The return rate for AFS/Food Stamps was eighty-seven percent with eight percent refusing to complete questionnaires and five percent failing to respond for "other" reasons. For SSA/SSI, the return rate on completed questionnaires was eighty percent, refusal to complete questionnaires at a rate of twelve percent, and failure to respond for "other" reasons represented seven percent. The lower rate of return for SSA/SSI may be attributed to a high rate of refusal in one of the largest rural branch offices in the sample (thirteen workers--fifty percent--refused to complete the questionnaires). This office employed twenty-six workers representing twentyone percent of the SSA/SSI sample population. No reasons were given for the high rate of refusal.

\section{Limitations of the Study}

The sample population is not a random sample, therefore, it may not be representative of the total population. This research is an exploratory study. Ideally, a random sample of line workers throughout the state could have been chosen, giving all line workers an equal chance of being selected. Due to the logistical constraints of time 
and travel costs, real limitations were placed on the data gathering methods and ultimately on the sampling procedure. The data from this study are subject to further limitations in that generalizations cannot be made about all line workers based on these findings. The only statement which can be made is that certain attitudes were observed in a sample of line workers in the state of Oregon. Further generalizations cannot be made with any pretense of accuracy of prediction.

Every effort has been made to avoid biasing the data or its analysis. Introduction of the study and directions for completing the questionnaires were carefully duplicated in each agency, and discussion of any issues was avoided until questionnaires were completed and returned. The fact that a number of respondents were not present for introductory remarks and instructions and returned questionnaires by mail, may affect the results simply because they were not given instructions by the interviewer and may have discussed issues with co-workers who had previously completed questionnaires. Field Representatives in SSA/SSI rural offices were often absent despite scheduling attempts, and in the case of one AFS branch office, twelve of thirteen WAW and Social Service Representatives were absent due to a last minute, unscheduled meeting (nine of these workers returned completed questionnaires by mail).

The survey instrument was used for the first time in this study. A pretest was conducted with the cooperation of graduate students at the Portland State University School of Social Work, and the instrument was revised prior to actual use in the survey. On the basis of this survey, there is no way to test the reliability of the instrument or the 
validity of the data collected. Although it appears that there have been no halo effects or other reliability problems in the three question sections of the instrument, further claims to reliability and validity are not made. Recommendations for further development of the instrument are discussed in Chapter $V$. 


\section{CHAPTER IV}

\section{RESEARCH FINDINGS}

To determine if there were statistically significant differences in attitudes and ideology of line workers based on an urban-rural comparison, and to determine if Warren's Paradigm I/Paradigm II conceptual model would predict the urban and rural response based on these data, a stepwise discriminant factor analysis was used. Clarkson (1978) provides a brief description of discriminant functions as they relate to this study:

Discriminant functions are used to discriminate among two or more groups on the basis of more than one variable. In its most direct interpretation a discriminant produces results equivalent to a t-test except that more than one variable is involved. In this particular problem a stepwise discriminant function procedure was used in order to assess the relative importance as differentiators of the various measures made on the rural and urban groups.

The stepwise discriminant analys is identifies the single best predictor (in this case the predictor of urban and rural) out of a given set of questions or items, combines this item with the next best item (conditioned on the first), and the next with the previous ones in descending order through the set until all items are included in the analysis. At each level of the analys is the U-value, or ability to discriminate the variable, is given in combination with the single best predictor (the value of each item conditional on the presence of the best predictor in the set).

The value of the U-statistic ranges from one (indicating no 
correlation) to zero (indicating perfect correlation). To interpret the meaning of the U-value, an F-distribution is used to test the significance leve1 and determine the degrees of freedom (in effect, the statistic $U$ is converted to an approximate $F$ value).

Item eleven in the first section dealing with the causes of poverty ("Many low income individuals want to participate in the job market but are blocked by the market itself") was shown to be the single best predictor of the urban/rural response (see Table I). The difference between the urban and rural response on this item was significant at the .05 level. The mean response for the rural sample on this item was 5.32 on the scale; for the urban sample the mean response was 5.89 . Although the item will discriminate between urban and rural at a statistically significant level, the mean scores of both groups lie in the center of the scale, making prediction based on the Paradigm I/ Paradigm II model difficult.

No items in the second section of the questionnaire (on Programs to Fight Poverty) were found to be discriminants of urban or rural. In the third set of questions dealing with the role of the worker, Item one ("The principal efforts of workers should be to help poor people gain psychological insights into the causes of their poverty") was found to best discriminate the rural response (this was the one best predictor of urban-rural in the entire questionnaire).

This item was shown to discriminate between urban and rural at the .05 level of significance (see Table I for F values). Although this is a Paradigm I item, prediction cannot be made on this basis because of the relatively small difference between the urban-rural mean responses 
TABLE I

DISCRIMINANT FACTORS IN PREDICTING

THE URBAN-RURAL RESPONSE IN

SECTION I AND SECTION III*

\begin{tabular}{cccc}
\hline & Mean & Value & Signifi- \\
Item & Response & of & cance \\
& On Scale & $F$ & Level
\end{tabular}

Urban $\quad \underline{\text { Rural }}$

SECTION I

ITEM 11:

The poor want to participate in the job market but are blocked

5.89

5.32

4.41352

.05

by the market itself

\section{SECTION III}

\section{ITEM 1 :}

The principal efforts of workers should be to help poor people gain psychological insights into the causes of their poverty.

$\begin{array}{llll}6.57 & 5.86 \quad 7.60667 & .05\end{array}$

F Matrix df $=1$ and 267

$n=269$

*Because no variable in Section II of the questionnaire would predict urban-rural at a statistically significant level, the section is omitted in this table.

on the scale and the fact that the mean responses are in the center of the scale. The most accurate statement which can be made is that based solely on Item one, Section III of the questionnaire, some factor loading occurred, significant at the .05 level, and that rural respondents 
showed lower mean scores on this Paradigm I item than did urban respondents. The two populations (urban and rural) appear to be highly similar in their responses on all of the thirty-six items. Even where there are statistically significant differences at the .05 level, these differences are not basic enough to predict urban and rural attitudinal differences based on the Paradigm I/Paradigm II conceptual model.

\section{Paradigm I/II as Discriminators of Ideology}

Based on these data, the stepwise discriminate analysis shows that, although there are some significant differences between urban and rural line workers' attitudes about poverty, these differences are not basic enough to draw conclusions about these two samples based on the Paradigm I/II distinctions. To determine if Paradigm I/Paradigm II would discriminate ideologies, Wyers (1978) constructed Chi Square ( $\left.X^{2}\right)$ tables (using these data) for each of the three sections of the questionnaire based on the total number of all possible responses in each of the three sections (see Table II).

Although there is more uncertainty of response (response on the scale of 5 to 10 ) in the first section dealing with the causes of poverty, Paradigm I responses are significantly more pervasive than Paradigm II responses in this section according to Wyers. In the sections dealing with programs to fight poverty and on the role of the worker, the responses predominantly reflected Paradigm I ideology over Paradigm II. All of these findings are significant at the .05 level, and show that, based on these data, this sample of Oregon line workers display attitudes and thinking which reflect Paradigm I ideology. Following is an analysis of each of the three sections of the 


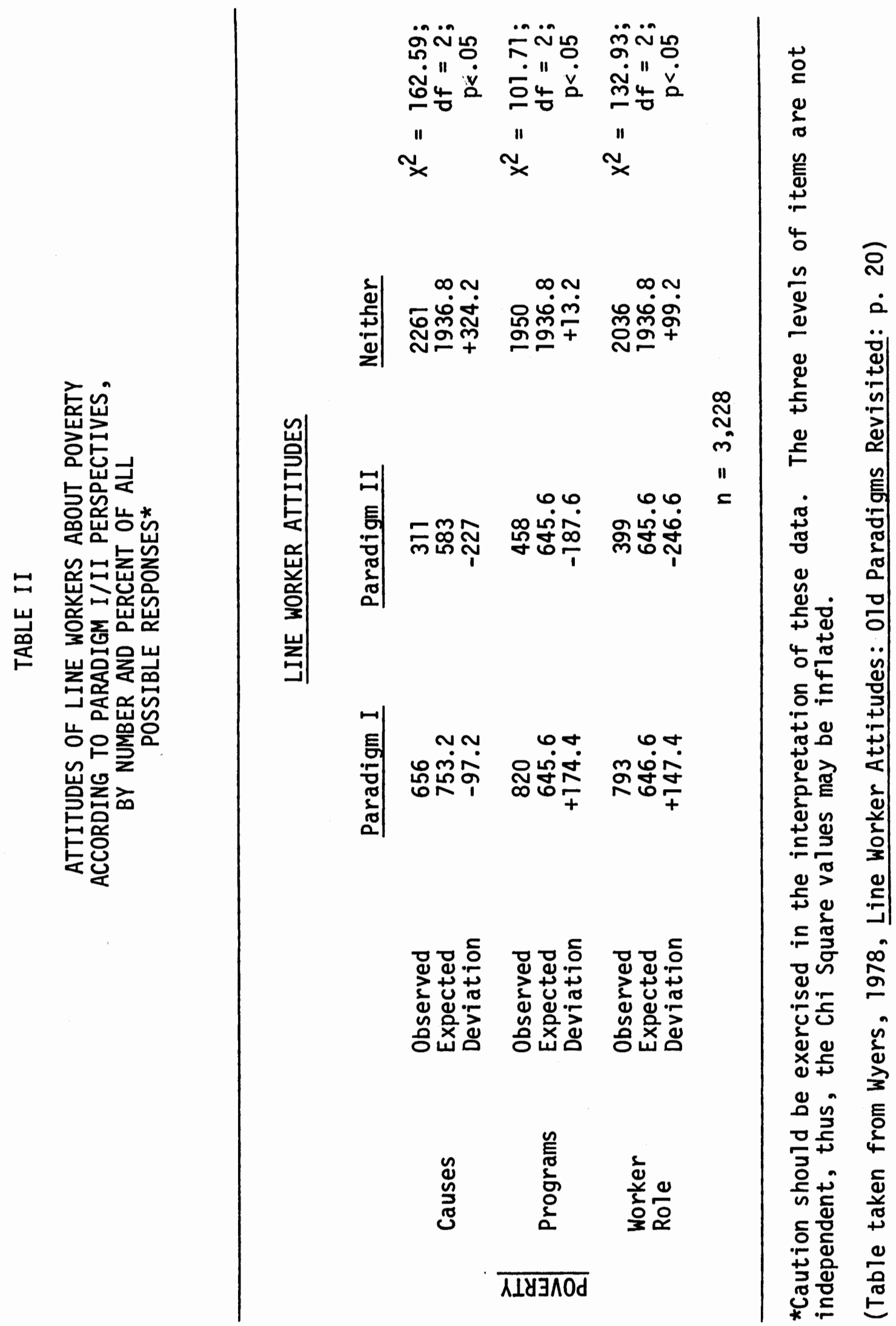


questionnaire based on the six best paradigm predictors (Items in each section in which the greatest degree of agreement or disagreement of response was measured) in each section.

Even though there was less certainty of response in the first section of the questionnaire dealing with the causes of poverty, there was more disagreement with items suggesting that the dynamics of the Capitalist economy, lack of jobs, or the dependency of the economic system on the availability of a low income labor market are important variables in causing poverty. There was more agreement with items suggesting that the failure of families to instill values of self help and motivation, the immediate environment of the poor, and the lack of education contribute to causing poverty (see Table III).

On the second section of the questionnaire dealing with programs to fight poverty, respondents agreed strongly with Paradigm I statements that "Proper education would help children of poor families break out of the cycle of poverty" and that work training programs should be integral parts of public assistance programs as a requirement (see Table IV). On these two items (\#11 and \#12) respondents indicated that the poor need to be educated and they should be required to work in order to gain motivation for self maintenance.

There was fairly strong disagreement with the Paradigm I statement (Item 4) that the poor are so unmotivated and dependent that little could be done to change them and that few resources should be expended on them. Apparently respondents believe that although the poor are unmotivated (as indicated in item 12 in this section), they can be changed and that some resources should be spent on them. 


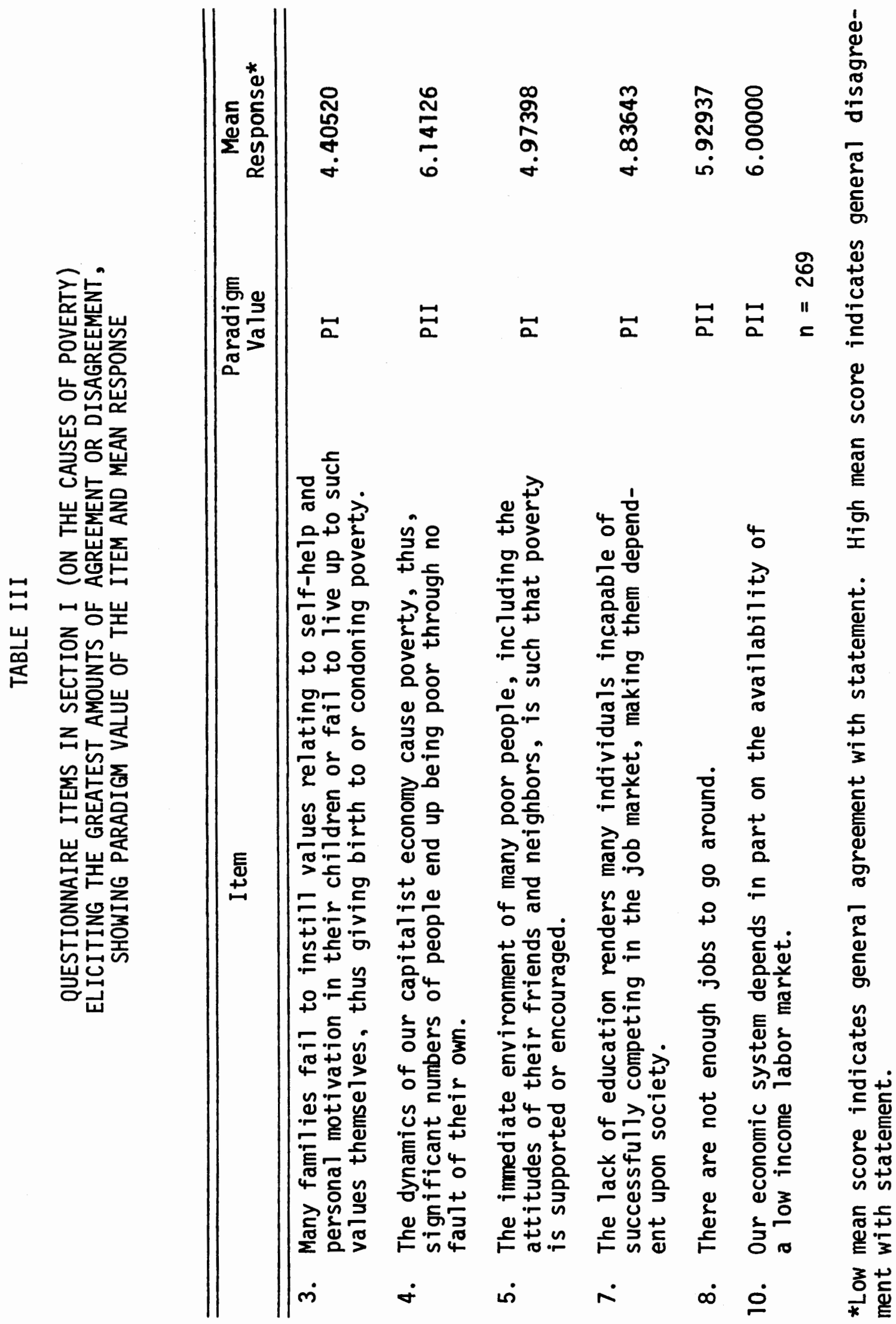


Overa11, there was very strong disagreement with statements indicating that benefits should be increased, work requirements, means tests, and eligibility requirements be abolished, and cash transfers to poor people or guaranteed annual incomes should replace public assistance programs (Items \#1, \#8, and \#9).

On the third section of the questionnaire dealing with the role of the worker, respondents agreed strongly with Paradigm I statements suggesting that workers should be supportive and understanding of their clients; that clients should encourage poor clients to acquire educational and work skills to enable them to better support themselves (see Table V).

High mean scores indicating general disagreement with certain Paradigm I statements (Items \#1 and \#6) suggest that workers do not see their principal roles as helping poor people gain psychological insights into causes of poverty or helping poor people to change immoral/illegal behavior. Workers did indicate strong disagreement with Paradigm II statements suggesting that political activism and helping clients to understand how they are being victimized by the economic system are legitimate activities for line workers working with poor people.

Hypotheses

Because Conceptual Paradigm I/Paradigm II does discriminate ideology, the Nul1 Hypothesis $(i-a)$ can be rejected at the .05 level of significance. In terms of the attitudes and ideological differences between urban and rural line workers, statistically the Null Hypothes is ( $i-b)$ can be rejected at the .05 level of significance, although based 


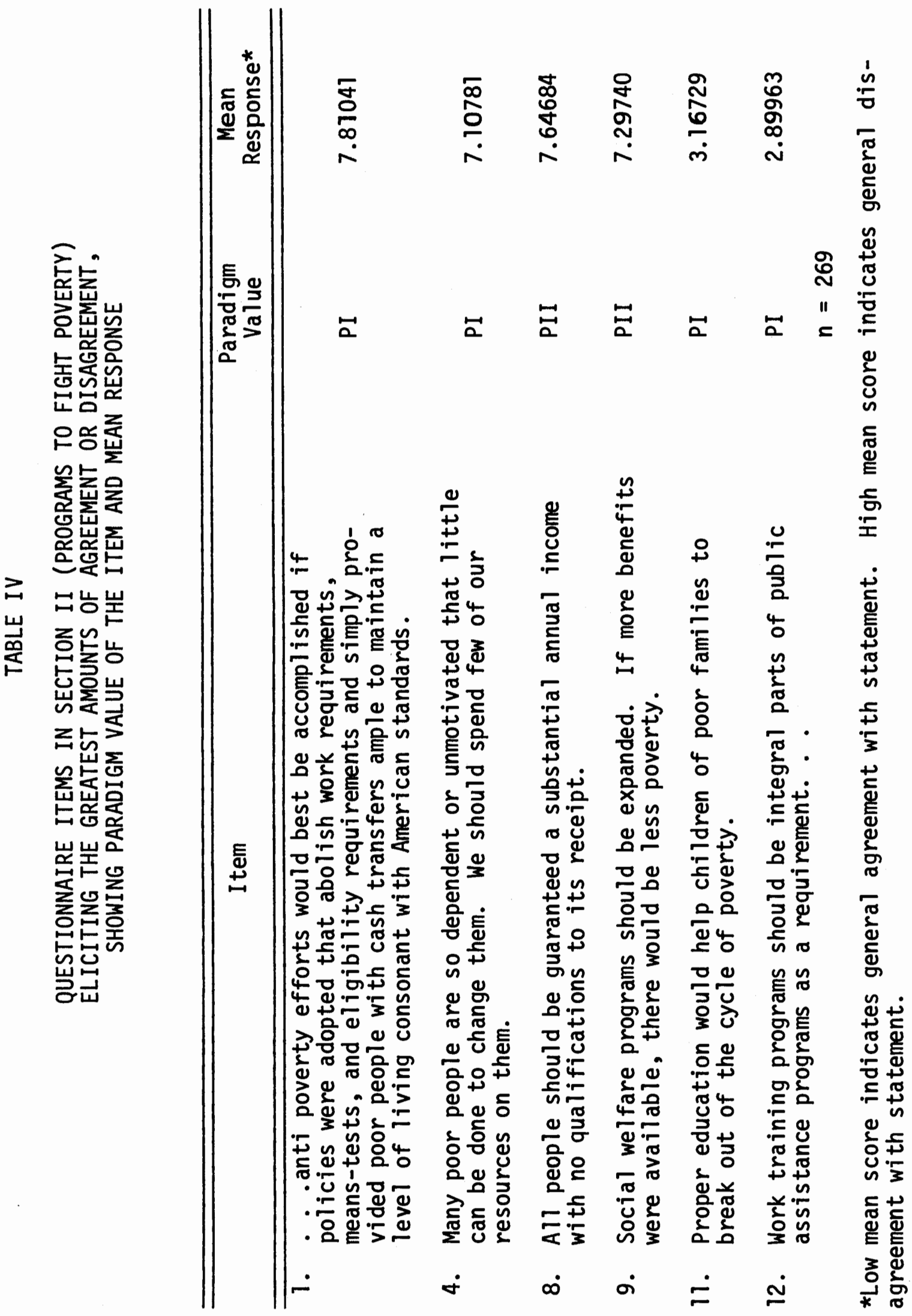


on these data, predictions of distinction cannot be made using the Paradigm I/II model. The nature of these differences in attitudes and ideology between urban and rural line workers is unclear at this time. More research is needed to clarify these differences.

\section{Sample Population}

The population of line workers in the urban sample appears to be similar to that of the rural sample in terms of the various demographic and biographic variables. The typical worker in this study lives and works in a rural area, is a female between the ages of twenty and forty, holds a Bachelor's degree in either the social sciences or in another field not related to social work and obtained the degree at a west coast school after 1960. The typical respondent has been working in the field of social services for five years or less and has been in her present position for between one and five years.

There are some slight differences in these factoral categories between the two populations which should be noted. There is a slightly higher percentage of female workers in the urban sample than in the rural sample. Sixty-eight percent of the urban sample are female workers and in the rural sample, sixty-three percent of the respondents are female. Another difference which should be noted is that a higher percentage of urban workers obtained their academic degrees after 1970 (forty-two percent in the urban sample as compared to thirty-four percent in the rural sample). Also, a higher percentage of urban workers (thirty percent) have been working with poor people for a period of from one to three years (as opposed to twenty-three percent in the rural sample), while a higher percentage of rural workers reported 


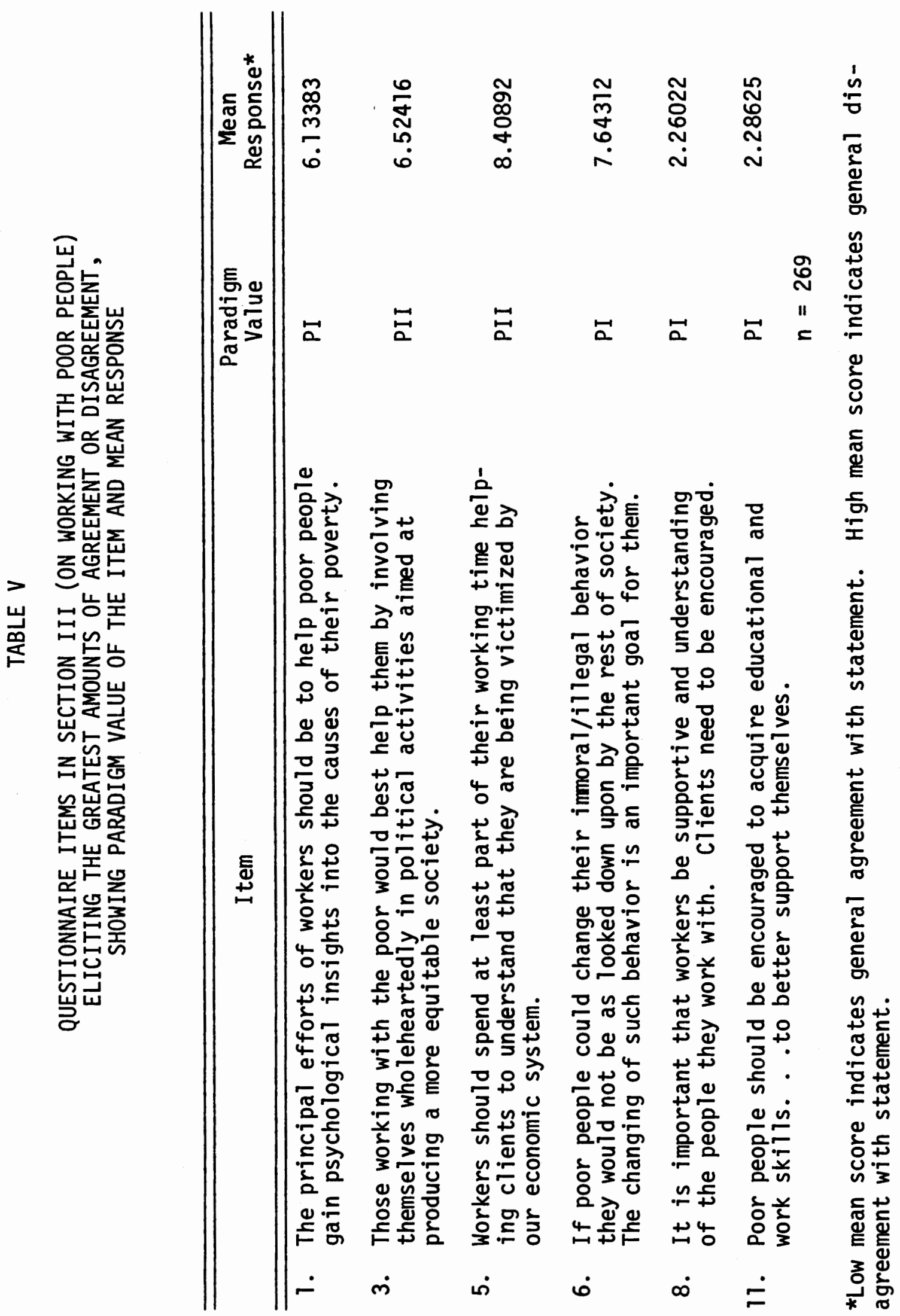


experience working with poor people in the category of from five to seven years (twenty percent of the rural sample compared to twelve percent of the urban sample).

The typical respondent in the survey came from a family where both parents were educated at the high school level. Typically, the respondent's father worked at a skilled blue collar job, and the mother was a housewife.

Predictably a higher percentage of rural respondents came from families where the father was a laborer or small farmer, but similar percentages of respondents whose fathers were professional or white collar workers were reported in both samples. More urban workers indicated that they came from families whose fathers were blue collar workers than did rural workers. Slightly higher percentages of urban respondents reported that their fathers had Master's or Doctorate degrees, while a higher percentage of rural respondents indicated their fathers had Bachelor's degrees or "some college."

Approximately forty-five percent of the rural workers came from families where the mother was a housewife compared to thirty-four percent of urban workers reporting similar backgrounds. A higher percentage of urban workers indicated that they came from families where the mother was a semiskilled worker (twenty-one percent) than did the rural workers (five percent). In terms of the mother's educational background, twenty percent of the urban sample reported mother's education as a Bachelor's degree or higher, as compared to nine percent of the rural group reporting the same educational level of the mother. 
Caseloads, Persons Serviced Per Month, and Job Title

The typical line worker in the survey is a Welfare Assistance Worker (WAW in an Adult and Family Service agency working with the Public Assistance programs), has a caseload of 150 clients or less, and provides public assistance services to $150 \mathrm{clients}$ per month. The size of the caseload varied substantially, both on an urban-rural basis, and categorically under the respective urban and rural headings (see Table VI). Over thirty percent of the urban workers reported caseloads of between fifty-one and one hundred cases (compared to the rural response of thirteen percent for this category). Thirty-four percent of the rural line workers reported caseloads in the categories between 151 and 300 cases, while only twenty-three percent of the urban workers reported caseloads in these categories. In the final category (301 or more) twelve percent of the urban workers reported caseloads of this size compared to eight percent of the rural respondents.

The item "Persons serviced per month" (see Table VII) was included in the survey to gain some understanding about how many persons the line worker has actual contact with over a one month period, i.e., out of a given caseload, how many persons does the line worker actually deal with? A common response to this question was that many of the persons that the line worker comes into contact with are not officially on the worker's caseload but have come into the agency for the first time, or are making inquiries by phone or in person. The typical line worker provides some type of service, i.e., giving information or other assistance, determining eligibility, making recommendations as to 
other types of services available and the like, to between fifty-one and two hundred persons who may or may not actually be on the worker's caseload.

In terms of job title, the largest categorical percentages recorded in both the urban and rural samples were the Welfare Assistance Workers (WAW's accounted for thirty-six percent of the urban and fortyeight percent of the rural samples). Adult Service Workers comprised seventeen percent of the urban and nineteen percent of the rural samples employed by AFS. In the Social Security offices, twenty-seven percent of the urban sample were Claims Representatives, while only eighteen percent of the rural sample filled similar roles. Finally, Service Representatives comprised fourteen percent of the urban sample and seven percent of the rural sample employed by the Social Security Administration.

\section{Major Program Area}

Although it may be generalized from the data that the typical worker in the study works with the Public Assistance program (fortyone percent of the urban and forty-three percent of the rural sample), closer examination reveals some differences between the two major program areas (SSA/SSI and AFS/Food Stamps). The major difference between the two general programs is the extent of worker role differentiation. Eighty-five percent of the urban respondents working in the AFS agencies worked specifically in the Food Stamp program or in the Public Assistance programs (seventy-four percent in public assistance and eleven percent in the Food Stamp program). The remaining fifteen percent worked in both programs. Rural workers in 
TABLE VI

SIZE OF WORKER'S CASELOAD ACCORDING TO URBAN AND RURAL CLASSIFICATION, BY NUMBER AND PERCENT

\begin{tabular}{|c|c|c|c|c|}
\hline Size & $(n)^{U r}$ & & $(n)^{\mathrm{Ru}}$ & $\begin{array}{l}\text { ral } \\
\% \\
\end{array}$ \\
\hline $\begin{aligned} 301 & \text { or More } \\
251 & -300 \\
201 & -250 \\
151 & -200 \\
101 & -150 \\
51 & -100 \\
1 & -50\end{aligned}$ & 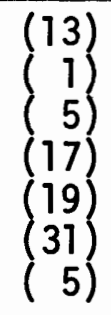 & $\begin{array}{r}13 \\
1 \\
5 \\
17 \\
18 \\
30 \\
5\end{array}$ & $\begin{array}{l}(14) \\
(10) \\
(17) \\
(30) \\
(28) \\
(22) \\
9)\end{array}$ & $\begin{array}{r}8 \\
6 \\
10 \\
18 \\
17 \\
13 \\
5\end{array}$ \\
\hline \multirow[t]{2}{*}{ No Response } & (12) & $\frac{12}{101}$ & (36) & $\frac{22}{99}$ \\
\hline & \multicolumn{2}{|c|}{$\begin{array}{l}\text { Urban } n=103 \\
\text { Rural } n=166\end{array}$} & & \\
\hline
\end{tabular}

TABLE VII

PERSONS SERVICED PER MONTH ACCORDING TO URBAN AND RURAL CLASSIFICATION, BY NUMBER AND PERCENT

\begin{tabular}{|c|c|c|c|c|}
\hline $\begin{array}{l}\text { Persons } \\
\text { Serviced }\end{array}$ & \multicolumn{2}{|c|}{$\begin{array}{r}\text { Urban } \\
(n)^{\%}\end{array}$} & \multicolumn{2}{|c|}{$\begin{array}{r}\text { Rural } \\
\text { (n) } \% \\
\end{array}$} \\
\hline $\begin{aligned} 301 & \text { or More } \\
251 & -300 \\
201 & -250 \\
151 & -200 \\
101 & -150 \\
51 & -100 \\
1 & -50\end{aligned}$ & $\begin{array}{l}(11) \\
3) \\
(10) \\
(11) \\
(17) \\
(20) \\
(14)\end{array}$ & $\begin{array}{r}11 \\
3 \\
10 \\
11 \\
16 \\
19 \\
14\end{array}$ & $\begin{array}{l}(21) \\
(10) \\
(13) \\
(27) \\
(24) \\
(24) \\
(13)\end{array}$ & $\begin{array}{r}13 \\
6 \\
8 \\
16 \\
14 \\
14 \\
8\end{array}$ \\
\hline \multirow[t]{2}{*}{ No Response } & (17) & $\frac{16}{100}$ & (34) & $\frac{22}{101}$ \\
\hline & $\begin{array}{l}\text { Urbal } \\
\text { Rura }\end{array}$ & $\begin{array}{l}n=103 \\
n=166\end{array}$ & & \\
\hline
\end{tabular}


AFS offices revealed similar ratios in each of the role categories (Public Assistance sixty-two percent, Food Stamps twelve percent, and the remaining twenty-six percent of the workers involved with both programs). In the SSA/SSI offices, workers are less likely to be assigned to specific program areas. Thirty-five percent of the urban workers in these offices worked specifically in the SSA or SSI program areas (SSA twenty-two percent and SSI thirteen percent), while the remaining sixty-five percent worked with both programs. In the rural SSA offices, respondents working in these specific program areas comprised thirty-four percent of the SSA sample (twenty-six percent in SSA and fourteen percent in the SSI), with the remaining sixty-six percent working with both programs (see Table VIII).

Combining the urban and rural samples presents the overall comparison between the two programs. Combined, AFS workers in specific programs (Public Assistance or Food Stamps categorically) comprised seventy-seven percent of the AFS sample, with the remaining twentythree percent of these workers dealing with both programs. In the SSA/SSI offices, only thirty-four percent of the workers are assigned to specific program areas (SSA or SSI) while the largest percentage (sixty-six percent) work with clients of both programs (see Table IX).

\section{Educational Background and Educational Aspirations}

Typically, respondents believed their educational backgrounds assisted them in meeting the demands of their jobs. Thirty-eight percent of the urban respondents and forty-eight percent of the rural respondents believed their educational backgrounds assisted them in meeting the demands of their job positions. Only twenty-four percent 
TABLE VIII

MAJOR PROGRAM AREA OF RESPONDENT ACCORDING TO

URBAN AND RURAL CLASSIFICATION,

BY NUMBER AND PERCENT

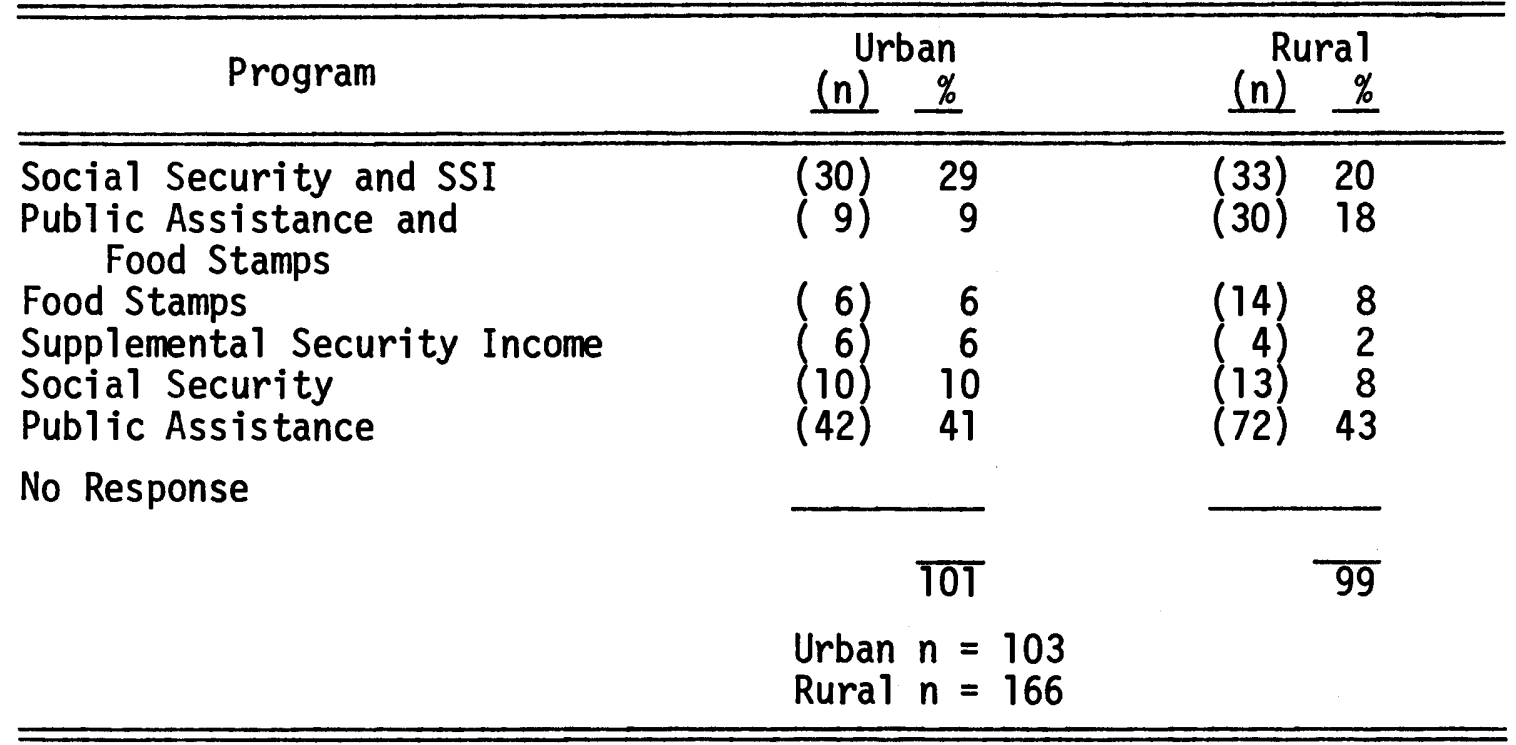

TABLE IX

COMPOSITE COMPARISONS OF MAJOR PROGRAM AREAS

(SSA/SSI AND AFS/FOOD STAMPS),

BY NUMBER AND PERCENT

\begin{tabular}{|c|c|c|}
\hline Program & $\begin{array}{c}\text { Number a } \\
(n)\end{array}$ & $\begin{array}{c}\text { Percent } \\
\% \\
\end{array}$ \\
\hline \multicolumn{3}{|l|}{ SSA/SSI } \\
\hline $\begin{array}{l}\text { SSA and SSI (Mix) } \\
\text { SSA } \\
\text { SSI } \\
\text { AFS/FOOD STAMPS }\end{array}$ & $\begin{array}{l}(131) \\
\left(\begin{array}{c}48) \\
(21)\end{array}\right.\end{array}$ & $\begin{array}{r}66 \\
24 \\
10 \\
100\end{array}$ \\
\hline $\begin{array}{l}\text { Public Assistance and } \\
\text { Food Stamps (Mix) } \\
\text { Public Assistance } \\
\text { Food Stamps }\end{array}$ & $\begin{array}{l}(42) \\
\left(\begin{array}{r}138) \\
(23)\end{array}\right.\end{array}$ & $\begin{array}{r}23 \\
66 \\
\frac{11}{100}\end{array}$ \\
\hline
\end{tabular}


of all the respondents believed their educational backgrounds adequately prepared them to meet the demands of their job positions (twentyeight percent of the urban sample and twenty-two percent of the rural sample). Twenty-eight percent of the respondents in the survey said their educational backgrounds were of little or no value in preparing them to meet job demands. Thirty percent of the urban and twenty-six percent of the rural sample indicated that educational backgrounds were of little or no value in meeting these demands.

When asked about the likelihood of obtaining additional education or a higher degree (respondents were free to choose more than one selection on this question; therefore, all responses will not add up to 100 percent), forty-nine percent of the workers indicated a great or probable likelihood of obtaining additional education, forty-one percent said it was not likely or non-existent, and six percent did not know. Forty-eight percent of the rural workers and fifty percent of the urban workers said the likelihood of additional education was probable or great; forty-three percent of the rural and thirty-nine percent of the urban workers said it was not likely or non-existent. Although fewer than fifty percent of the workers indicated that there was a good possibility they would obtain additional education, forty-one percent of the respondents believed that counseling would help them in present job roles, thirty-seven percent believed that psychology would be of help, and thirty-four percent would turn toward social work. (These responses were not broken down categorically on the basis of urban and rural).

When asked about their major areas of educational deficiency, 
forty-two percent of the respondents indicated they were most deficient in understanding the historical/philosophical analyses of poverty, thirty-one percent said they were most deficient in their understanding of psychopathology, twenty-three percent felt they were deficient in understanding organizational theory, and an additional twenty-three percent indicated they were deficient in understanding theories about poverty (again, respondents were free to make more than one selection). (These responses were not broken down categorically on the basis of urban and rurat.)

In the biographical and educational sections of the questionnaire, overa 11 the average rate of non-response or refusal to respond was approximately seven percent. This rate of non-response was higher in the rural sample than in the urban sample for each question. The overall non-response rate of the rural sample was eight percent as compared to a five percent rate of non-response for the urban sample. There is no indication why more of the rural line workers refused to respond to these questions.

Representativeness of Sample

The Public Assistance response in the study comprises sixty-three percent of the sample, the Social Security response comprising the remaining thirty-seven percent. According to Wyers (1978), Public Assistance line workers represent eighty-two percent of the line workers in Oregon and Social Security line workers represent the remaining eighteen percent. Thus, the Public Assistance population is underrepresented in the study and Social Security over-represented. Because no other claims of representativeness are made, generalizations about 
line workers in other areas or states cannot be made based on these data and on this study sample. More research is needed to provide base data for comparative studies of line workers in other areas and/or other states.

\section{Discussion of Findings}

The results of this survey supported the original hypothes is that the conceptualized categories Paradigm I and Paradigm II would differentiate ideologies of line workers. Chi Square tables were constructed based on composite comparisons of the amounts of Paradigm I or Paradigm II content of response in each section of the questionnaire, taking all responses into account. In each of the three sections, Paradigm I responses were shown to be significantly more pervasive than Paradigm II.

In the first section of the questionnaire (on the causes of poverty), respondents showed more uncertainty of response than in the latter two sections (programs to fight poverty and the role of the worker), although responses indicating that poverty was the result of individual dysfunctions (Paradigm I) were predominantly favored over those suggesting that poverty was more often the result of a social/ structural problem (Paradigm I).

These findings are consistent with those of Hussmann (1976) and Dominick (1977), and support the findings of Arangio (1970) (see Chapter II). In her study of the attitudes of a group of social workers, based on Warren's Paradigm I/II model, Hussmann reported responses predominantly favoring Paradigm I solutions to alleviating poverty and working with poor people. The author concluded that "direct service workers 
were found to be more likely to focus on individual change and growth than on organizational or institutional change in their work" (Hussmann, 1976: 48).

Dominick studied the attitudes and ideology of juvenile delinquency workers using Warren's hypothesized categories. Three general question areas (similar to those of this study) were used (causes, programs, and the role of the worker). Although Dominick found more uncertainty of response in worker's attitudes about the causes of juvenile delinquency, he concluded that respondents in his study perceived a clear distinction between Paradigm I and Paradigm II concepts. Juvenile workers showed strong agreement with Paradigm I concepts, a)though there was a trend toward some agreement with Paradigm II statements relating to working with community organizations which affect youth. Dominick concludes that, "Overal1, there was disagreement with statements emphasizing the present social structure as causative of delinquency" (Dominick, 1977: 104). These findings are also consistent with those of Arangio who found that most social workers were strongly oriented toward individual change and disagreed with social change tactics or strategies.

Implications of Paradigm I Ideology

If, as these data suggest, line workers believe that poverty is largely the result of individual deficiency or dysfunction, that programs should focus mainly on working with individuals and their problems, and that the traditional roles of the worker (those concentrating on developing work motivation, work and personal management skills, and the like) are the only legitimate roles, what are the implications 
related to prevailing social values and ideology? What are the implications of Paradigm I attitudes and beliefs in terms of how line workers relate to clients and, in turn, how clients feel about programs?

Finally, what are the implications for schools of social work education as these values relate to theories and rationales for practice being taught?

As Schiltz (1970) has noted, the prevailing ideology of this society is still tied heavily to the Puritan ethic of hard work and rugged individualism. The basic notion of this ideology is that any normal person can take care of him/herself if he/she tries hard enough, and that each individual should be responsible for self-maintenance through hard work. The converse of the ideology suggests that it is the abnormal person, the lazy person, or the deficient person who is poor. There is no reason to believe that line workers do not support and regard this Paradigm I ideology as true and right.

If administrators and line workers in these programs are carrying out a socially mandated charge that, in a direct sense, opposes the prevailing ideology, what is the result of this double bind situation in terms of how workers relate to clients? Based on the Paradigm I notion (inherent in the ideology) that poor people are lazy, unmotivated, or have other problems which, due to individual deficiencies, contribute to a lack of ability to take care of themselves; that many poor people will try to cheat the system; and that benefits are a privilege granted by society, it is likely that line workers view clients through an air of distrust and close scrutiny. It is also likely that line workers (because of the public mandate which allows them to distribute 
privileges in the form of benefits and services to people considered "not normal" and often unworthy) may consider themselves "guardians" of the public purse. As Handler and Hollingsworth have suggested, if benefits are given in an air of distrust or suspicion, recipients are going to feel stigmatized in receipt of such benefits. If, indeed, the attitudes of the line workers in these programs contribute to the stigmatization of recipients, the result may be reflected in underutilization of programs by eligible persons. Wyers (1976) found that stigma related to income maintenance programs was a contributing factor in underutilization of these programs by eligible persons. Perhaps it is time to reassess our ideological perceptions about the poor both at the social level and at the level where attitudes are translated into direct action in the form of relief benefits and the manner in which they are given.

\section{Social Work Education}

Although only one percent of the line workers surveyed in this study had social work backgrounds, the data point to a number of areas which should be of some concern to social work education in terms of theories and methods being taught and ideologies and attitudes being supported. Questions for any social work program self-evaluation may include:

--Is the particular social work school curriculum perpetuating the Paradigm I ideology of "rugged individualism" by concentrating too heavily on theories of individual change and growth, i.e., Freudian theory, as suggested by James (1972) (see Chapter II)?

--Are new social workers being prepared to effect social change 
through their jobs, or are they merely being prepared to fit into prescribed roles, i.e., the traditional roles considered legitimate (often reflecting Paradigm I notions about working with poor people) in social welfare programs?

--What is the professional orientation of the school in question? Does the school support a profession caught up in trying to gain professional status through the conservative channels of licensing, private practice, medical model practice orientation, and other methods designed not to rock the "social boat"?

--What kinds of advocacy or social change strategies are being taught? Is the school of social work teaching the traditional change or advocacy strategies involving socially legitimate methods or is it also teaching methods of non-institutionalized strategies as suggested by Epstein (1968) (see Chapter II)?

--What are the goals and objectives of the school as reflected by the rationale for its purpose (the school's creed or statement of purpose)? Do goals and objectives reflect Paradigm I or Paradigm II ideology? Is the school's curriculum consistent with the creed or statement of purpose in terms of the Paradigm orientation suggested by the statement or creed?

The curriculum of any social work program will reflect the school's basic ideological orientations about the causes of poverty. If the curriculum is inconsistent with the stated purpose of the school (i.e., methodologies and theories reflecting Paradigm I ideology being taught in opposition to a statement of purpose reflecting a Paradigm II orientation), it is the statement of purpose (the basic ideological 
orientation of the program) which is in question. As noted by Warren in his definition of the concept, a particular Paradigm implies strategies to deal with the problem, technologies required, and the aspects of the total situation surrounding the problem singled out as unimportant or irrelevant (see Chapter I). In examining the orientations of a school of social work, a number of dimensions should be taken into consideration. First, the attitudes and ideologies of instructors must be examined. The content of any course (regardless of its ideal catalogue description) will reflect the ideological orientations of individual instructors, thus, the catalogue description of the program (while it may have some value in terms of presenting a very general idea of the orientation of the program) will reveal little about the ideological orientations of the school. At best, new students are at the mercy of chance in trying to choose a school or program reflecting a particular ideological orientation, solely on the basis of the catalogue. This suggests another dimension for examination, that of the orientations of social workers who have graduated from a particular program. Where are they working, what jobs have they held, what are the prevalent attitudes of professionals who have come through the program, and how do they feel about what they were taught one, two, five, or ten years after graduation? Comparative studies of various schools examining these questions may be instructive in seeking to gain an accurate perception of the basic orientations of different schools, curricula, and teaching staffs.

Ideological Differences Between Urban and Rural Line Workers

The recent studies of Osgood (1977) and Wyers (1977) have 
addressed the basic attitudinal differences between urban and rural respondents relating to basic beliefs about poverty, programs to fight poverty, and poor people in general. Osgood compared the attitudes of urban and rural respondents in a statewide study in Pennsylvania and concluded that rural respondents were less likely to support welfare programs or be sympathetic to the welfare poor than residents of highly urban areas. The author also found that rural respondents were less likely to trust the honesty of recipients and doubted to a greater degree, the willingness of recipients to work (see Chapter II).

Based on data collected in the statewide Oregon Town Hall Meetings of July, 1977, which addressed questions relating to policy and programs dealing with poverty, Wyers reported basic differences between urban and rural responses (based on a comparison of composite responses in Oregon Congressional Districts). The author notes:

The lone urban Congressional district favored a guaranteed minimum ( 53 percent) more than other districts did. The most rural district was the strongest supporter of work requirements (22 percent) and the least supportive of the guaranteed minimum (24 percent). The urban district preferred job creation over other solutions to unemployment than the other districts did. The urban district was blatantly more generous in its definitions of income adequacy. Twenty-six percent of the respondents in that district indicated their belief that a fourperson family required at least $\$ 16,000$ per year and should be guaranteed that amount. Seventy-nine percent of those in the same district were willing to pay higher taxes to achieve such a result. Only forty-two percent of those in the rural district were willing to assume a greater tax burden. (Wyers, 1977: 23)

Wyers concludes:

The urban American, if these findings can be assigned any importance, views society much differently than does his/her rural counterpart. Repeatedly, many of the sharpest differences among respondents of the Town Hall meetings were those influenced by geography or by the degree of urbanism experienced by the respondents. (Wyers, 1977: 23) 
Based on the findings and conclusions of both Wyers and Osgood (although these studies did not examine line worker's attitudes, they did compare attitudes of respondents on an urban/rural basis), the writer suspected that differences in the attitudes and ideology of 1 ine workers according to the urban and rural classifications would be clearly distinct based on the hypothesized categories of Paradigm I/II. Such was not the case. Although Paradigm I and Paradigm II were found to discriminate ideologies, discrimination did not break down along the lines of the urban and rural classifications. Some statistically significant differences were found (as shown by the stepwise discriminate factor analysis described earlier in this chapter), but these differences were not basic enough to be assigned Paradigm values. These data are not sufficient to describe the urban and rural differences indicated by the factor analysis. The writer can only speculate about alternative postulates in discussing these differences in light of the conclusions of Wyers and 0sgood and the findings of this study. Some alternative postulates are:

--The studies of Wyers and 0sgood did not examine or address the attitudes or ideologies reflected by the Paradigm I/II conceptual categories. Implied here is the notion that the studies were not meant to discriminate the Paradigm I/II ideologies.

--The attitudes of line workers are not reflective of the attitudes of the greater society, i.e., the attitudes of urban line workers are not consistent with, or reflective of, the attitudes of the general urban population (line workers are generally more conservative in their ideological orientations about the causes of poverty and programs to 
fight poverty). Although this is a possibility, it is not consistent with earlier conclusions of Schiltz (1970), Grosser (1973), Galper (1975), and Leonard (1975) who individually conclude that social services in this country have historically and currently supported capitalism, the Puritan work ethic, and the idea of rugged individualism (see Chapter II).

--The respective sample populations of Wyers and Osgood were not representative of their respective state populations.

--Conversely, the sample population of this study is not representative of all Oregon line workers in terms of the urban and rural classifications.

--Ideological differences between urban and rural line workers are more basic than can be predicted by the hypothesized categories (Paradigm I/II).

--Although the instrument used in this study was sufficient to discriminate between the hypothesized categories (Paradigm I/II) at a statistically significant level, it was not sufficient to discriminate urban and rural attitudes, i.e., the questions did not address the attitudinal differences between urban and rural respondents.

--In reality, the conceptual Paradigm I and Paradigm II categories have little or no relationship to the prevailing social ideology (the Puritan work ethic and the idea of rugged individualism), i.e., the conceptual categories do not measure ideology at all, but something else altogether.

Based on these speculative possibilities and the discussion of the findings, the writer has made some recommendations for future study and 
further analysis of attitudes and ideology as they relate to social work education and future examination and comparison based on the urban and rural categories of income maintenance line workers (see final section, this chapter).

\section{Feedback From Respondents}

Although items were responded to in relation to an attitude scale, respondents were encouraged to include comments regarding issues raised by the items and/or comments about the questionnaire itself. Over twenty percent of the respondents did provide valuable feedback in the form of written comments in their returned questionnaires. Most comments dealt specifically with issues raised by various items, while fewer than one percent of the respondents commented directly about the questionnaire.

of those who provided feedback on the construction of the questionnaire, most respondents made comments about specific questions. Some respondents felt that certain questions addressed more than one issue. While they agreed with one part of the question or statement, they disagreed with another. The two items presenting the most difficulty were Item 4 - Section II and Item 9 - Section III. On Item 4 in the second section, respondents agreed with the statement that many poor people are dependent and unmotivated but disagreed with the statement that little could be done to change them. They also disagreed that few resources should be expended on the poor. On Section III, Item 9 , respondents indicated that workers should help clients to develop better budget and personal management skills, but disagreed that poor skills in budget and personal management were a cause of much 
poverty.

A second criticism of the questionnaire was that some of the items were too general or sweeping as to be simplistic in explaining the causes of poverty. Respondents agreed that the causes of poverty were varied and interrelated and could not be isolated into individual causation factors. A number of respondents substituted the word "some" for the word "much" or "many" in statements which referred to "much poverty caused by. . .," or "many people are poor because. . .," as in Section I - Items 11 and 12; Section II - Items 4 and 6; and, Section III - Item 9.

Where respondents could not respond to certain items as written, they altered or otherwise modified the statement to agree with their point of view, qualified their answers ("Depends on the situation," or "For certain people"), or added a completely new question in certain instances to address a particular issue or point of view. Only one respondent indicated that the questionnaire did not measure or address the issues and purpose of the study as stated in the introductory paragraph on page one of the instrument. This respondent did decline, however, to further elaborate on the comment.

\section{Comments on the Issues Addressed}

of the issues addressed, five issues elicited the most comment. These issue areas include: (1) values, motivation, and family background, (2) availability of jobs and the motivation to work, (3) client advocacy, (4) educational opportunity, and (5) the deserving and undeserving poor.

Many of the respondents who commented on issues indicated a 
strong belief that family background plays an important part in the development of seif-maintenance values and personal motivation to pursue work and educational goals. Related to this question of motivation, many respondents agreed that educational opportunities are available to anyone in this society, but that people must be motivated to apply themselves to take advantage of opportunities. Respondents were also in agreement that there are enough jobs, but that many poor people do not want to work or they do not want to do the unskilled jobs which are plentiful. Some respondents indicated that the aspirations of the poor are higher than their abilities and potential, i.e., they want to be paid higher wages than available jobs are worth, and they want jobs which require greater skill levels than what they have. Respondents agreed that work is important but that clients are not motivated (because of family background) to take jobs which are available.

In terms of the deserving and undeserving poor, respondents stressed that the elderly and disabled should receive more benefits in the form of "social insurance," and that few of the elderly and disabled are cheating the system. Few respondents stressed the idea that most recipients were cheating the welfare system, but indicated that prosecution of those who were cheating would provide a strong deterrent to other recipients.

Some respondents indicated a strong disagreement with the statement that workers should help the clients understand how they are being victimized by the economic system. It was felt that clients "feel sorry for themselves" already, and such behavior would only encourage a greater degree of self-pity. As far as advocacy of client's rights 
is concerned, respondents felt that they should encourage clients to demand their rights only through established legitimate channels of formal complaint and only when the actions of the agency were in direct violation of the law.

Some respondents commented on the section of the questionnaire dealing with the adequacy of their educational backgrounds in preparing them to meet job demand. Most of the comments in this section stressed the need for more "on the job" training. Respondents suggested that, although education was valuable for the most part, it was not consistent with the realities of working in the world of human services.

The writer believes that the comments of study participants were an important source of information in addition to the actual questions. The comments provided valuable clarification of specific issues as well as useful feedback in terms of further development of the questionnaire for potential future study.

\section{Implications for Additional Research}

Based on the findings of this study and the conclusions and results of the various studies reviewed in Chapter II, the need for further study and examination of the attitudes of workers in income maintenance programs has become apparent to the writer. The need for study and research (as well as introspective examination) of the various aspects of social work education is also apparent (curriculum, school policy, professional orientation, and program goals and objectives). Thus, the writer would make the following suggestions and recommendations based on the conclusions of this study and on the discussion of social work education in Chapter V: 
--More study needs to be done to determine the nature of the basic differences in attitudes and ideology of income maintenance line workers. Although it was determined that there are differences between urban and rural workers, it is not clear at this time what those differences are. In this vein, comparative research of the attitudes of line workers between different states would also be instructive. Such research could be conducted on two levels--first, comparisons between states with similar populations and other demographic features, and second, comparisons between predominantly urban and predominantly rural states. Such studies would provide valuable data for analys is and comparison.

--There is a great need for research into the various aspects of social work education. Research to provide data for comparative analysis between various schools is needed regarding curriculum and how and to what extent the curriculum supports and perpetuates the prevailing ideology of rugged individualism and the Puritan work ethic by concentrating on theories of individual change.

--More research is needed to determine and clarify the prevailing professional orientations of schools of social work. To what extent are schools supporting a status quo profession or a change oriented profession? If schools are teaching theories of social change, do the theories mainly support traditional, socially legitimate channels (Paradigm I) of change or non-institutionalized forms or strategies of change (Paradigm II)?

--Studies of schools' goals and objectives need to be done to determine if they reflect Paradigm I/II ideology and if they accurately 
reflect school policies, creeds, and statements of purpose. Also, such research should examine the curricula of respective schools to determine if curricula are reflective of, or consistent with, school creeds and statements of purpose.

--There is a need for more research to determine if social work education is meeting the needs of social workers entering the profession. Do social workers reflect the ideologies of the school one, two, five, or ten years after graduation? Do ideologies and attitudes change to meet job demands?

--Finally, more research is needed to examine possible determinants of Paradigm I/II ideology in the field, i.e., what will change ideology and/or attitudes after a social worker is in the field for a given length of time? 
CHAPTER $V$

\section{SUMMARY AND RECOMMENDATIONS}

\section{Purpose}

The purpose of the study was to measure the attitudes of income maintenance line workers about the causes of poverty, programs to fight poverty, and their roles as workers working with poor people. These attitudes were analyzed to first determine whether Roland Warren's Paradigm I/II conceptual categories would discriminate ideologies of workers, and second, to determine if there were any significant differences in the attitudes and ideology of urban and rural line workers in Oregon. It was hypothesized that Paradigm I/II would discriminate ideologies and that there would be attitudinal and ideological differences between urban and rural line workers.

\section{Literature Summary}

A review of the relevant literature was conducted. Literature reviewed included studies about the attitudes of the general public about the causes of poverty, anti-poverty programs, and poor people in general. Other studies surveyed the attitudes of poor people about their problems and anti-poverty programs, while another category of surveys addressed the attitudes of workers in a variety of programs at various levels and from a variety of backgrounds about their attitudes in regard to their clients, their jobs, and the programs in general. It was found that few studies have been done to measure the attitudes of 
social service workers about the causes of poverty, the poor, and the worker's role in dealing with poor people, although it was pointed out in the literature that line worker attitudes generally reflect the prevailing ideology of society (the Puritan work ethic and the idea of rugged individualism). At least three sources (Gartner, 1970; Handler and Hollingsworth, 1971; and Gilbert and Specht, 1974) indicate that the attitude and manner of the eligibility worker has a stronger bearing on how services are received by the client, underutilization of programs, and the client feeling stigmatized, than do the services, benefits, and program eligibility requirements (means testing and the like). Goodwin (1973) has expressed a need for studies which would examine "the perceptions of those who would help the poor."

Hussmann (1976) and Dominick (1977) measured the attitudes of social workers and juvenile delinquency workers respectively, using Warren's conceptual model. In both studies it was found that Paradigm I and Paradigm II did discriminate ideologies.

The literature search revealed six studies directly addressing the differences in attitudes of urban and rural populations. Five of the studies compared attitudes of residents on an urban/rural basis (Summers, 1969; Goudy, 1970; Wooster, 1972; Osgood, 1977; and, Wyers, 1977), and one study surveyed the attitudes of social science teachers (Roark, 1973). Each of these studies concluded that the rural samples tended to be less sympathetic to the poor and displayed attitudes more residual in nature. With the exception of 0sgood who alludes to possible differences in service delivery between rural and urban line workers (see Chapter II), no studies were found which directly addressed 
these differences.

\section{Summary of Methodology}

The study was conducted on a statewide basis (see Chapter III) and data collected using a thirty-six item questionnaire. Responses to each item were recorded using a nine-point modified Likert scale. Included in the questionnaire, along with the three separate question sections (The Causes of Poverty, Programs to Fight Poverty, and The Role of the Worker Working With Poor People), were sections dealing with biographical and educational background, agency information, and educational aspirations. Each question in the instrument was designed to reflect a specific Paradigm value (see Chapter III).

\section{Summary of Findings}

The data supported the original hypothes is that conceptual Paradigm I and conceptual Paradigm II would discriminate ideology (see Chapter IV. Wyers (1978) constructed a table of composite Paradigm responses to measure the amounts of Paradigm I/II response in each section (see Table II). Although there was more uncertainty of response in the first section (On the Causes of Poverty), the amount of Paradigm I response was greater than that of Paradigm II. In the remaining two sections of the questionnaire (Programs to Fight Poverty and On the Role of the Worker), response was found to be predominantly Paradigm I. Composite analysis was done using standard Chi Square and results were significant at the .05 level (see Table II).

A stepwise discriminate factor analys is (described in Chapter IV) was used to determine if there were any attitudinal differences between 
urban and rural line workers based on the thirty-six variables (see Tables I, III, IV, and V). Although there were some differences measured at the .05 level of significance (see Table I), these differences were not basic enough to describe on the basis of the hypothesized categories (Paradigm I/II). The findings of this study support the conclusions of Hussmann (1976) and Dominick (1977) and are consistent with the findings of Arangio (1970).

\section{Limitations of Study}

The major limitation (as outlined in Chapter III) of this study is that the sample population is not a random sample. Therefore, any statements of conclusions regarding the findings apply only to this sample population of Oregon line workers. The survey instrument was used for the first time in this study. A pretest was conducted previous to the study and revisions were made prior to the survey. There were some problems with certain items in the instrument (see the summary of respondent's comments in Chapter IV) and recommendations for further development and revision of the instrument have been made (see recommendations, this Chapter).

In terms of the representativeness of the sample, the Public Assistance population is under-represented in the study, and the Social Security population is over-represented.

\section{The Survey Instrument}

After using this instrument for the purposes of the present study, the writer would make the following recommendations in redesigning the instrument for future use. The main problem with the instrument was 
that each item addressed a specific Paradigm, but would only indicate the Paradigm value if the respondent agreed with or supported the statement (a response of one through five on the scale--see Chapter III). The way in which the statements were worded would not allow the researcher to conclude that a disagree response would indicate the opposite Paradigm. Thus, any responses of six through nine on any item were simply coded as mix or other. More precise data analysis could be facilitated if items would simultaneously address both Paradigm categories by either an agree or a disagree response. It is unclear at this time how certain items could be reworded, and careful pretesting of revised versions would be of paramount importance. A method of testing validity of such questions would be the inclusion of control questions in the questionnaire relating to each item.

Conclusion

This research adds to a growing awareness of the extent to which the Puritan work ethic still commands a predominant role in our national ideology. The ideology of line workers in income maintenance programs is highly consistent with the general ideology of our society. Poverty is still viewed as an individual problem (at least in Oregon by this sample of line workers)--individuals are still held ultimately responsible for their own poverty.

The Portland State University School of Social Work has the unique position of being the only school of social work in the state of Oregon. Many of its students are now, and will in the future, fulfill managerial and administrative roles in income maintenance and other social service programs. If, as Hoshino (1971), Epstein (1971), Armitage (1974), and 
Patti (1974) note, line workers are as likely as the executives of their programs to approve of more radical strategies of client advocacy (see Chapter III), the practice ideologies of future administrators of these programs should be of much concern to social work education. If the School of Social Work is directly impacting the social service community in Oregon by providing trained social workers (among various ways the school impacts the community), it is important that the School closely examine its ideology, the theories for practice being taught both in planning and direct service, and its goals and objectives as they reflect the School's basic ideology. The choice the School has to make is whether it is going to be a change agent in the community, or another organization in support of the professional and social status quo. The choice is never easy and steering a course once the choice has been made is, at best, difficult. Probably the initial course of action is to ascertain, through the above suggestions, the direction the School is going in, where it wants to go, the steps necessary to change the course if change is needed and desired, and the steps necessary to remain on course after the direction is clarified and chosen. 


\section{SELECTED BIBLIOGRAPHY}

Alston, Jon P. and K. Imogene Dean. "Socioeconomic Factors Associated With Attitudes Toward Welfare Recipients and the Causes of Poverty," Social Service Review, 46 (March, 1972): 13-23.

Arangio, Anthony Joseph. "Individual Change or Institutional Change: Attitudes of Professional Social Workers Toward Change Targets, Goa1s, and Tactics," Ph.D. Dissertation, (Tulane University, 1970).

Armitage, W. A. G. "A Structural View of Welfare Organizations," Practice of Social Work, (Belmont, California: Wadsworth Publishing Company, 1974).

Bentrup, Walter C. "The Profession and the Means Test," Social Work, 9 (Apri1, 1964): 10-17.

Brager, George A. "Institutional Change: Parameters of the Possible," Social Work, 12 (January, 1967): 59-69.

Clark, Kate M. "Social Workers and Social Action: A Study of Attitudes and Action," MSW Dissertation, (Smith College for Social Work, 1964).

Clarkson, Dean. Personal Correspondence, (February 15, 1978).

Dominick, Gary Lee, Carol Swartz, and Michael 0. Taylor. "The Attitudes of Youth Workers on Delinquency and Delinquency Programs," MSW Practicum, (Portland State University, 1977).

Epstein, Irwin. "Organizational Careers, Professionalization, and Social Worker Radicalism," The Social Service Review, 44 (June, 1970): 123-131.

"Social Workers and Social Action: Attitudes Toward Social Action Strategies," Social Work, 13 (Apri1, 1968): 101-108.

Feagin, Jol R. "America's Welfare Stereotypes," Social Science Quarterly, 52 (March, 1972): 921-933.

Freud, Sigmund. Civilization and Its Discontents, (Garden City, New York: Double Day Anchor Books, no date).

Galper, Jeffrey. The Politics of Social Services, (New Jersey: PrenticeHall, Inc., 1975). 
Gartner, Alan. "Services: Do the Poor Use Them?" Social Policy, 4 (November-December, 1970): 71-72.

Gilbert, Neil and Harry Specht. Dimensions of Social Welfare Policy, (New Jersey: Prentice-Hal1, Inc., 1974).

Goodwin, Leonard. "Middle Class Misperceptions of the Highlife Aspirations and Strong Work Ethics Held by the Welfare Poor," American Journal of Orthopsychiatry, 43 (January, 1973): 554-564.

Goudy, Willis J. "'Shoot Them if They Won't Work': A Study of Socioeconomic Status, Economic Aspirations, and Attitudes Toward Poverty, the Poor, and Public Dependence," Ph.D. Dissertation, (Purdue University, 1970).

Greenstein, Michael. "Opinions of Welfare Workers About Selected Welfare and Social Service Issues and About Recipients," DSW Dissertation, (Southern California, 1975).

Grimm, James W. and James D. Orten. "Student Attitudes Toward the Poor," Social Work, 18 (January, 1973): 94-100.

Grosser, Charles F. New Directions in Community Organization: From Enabling to Advocacy, (New York: Praeger Publishers, 1973).

- "Perceptions of Professionals, Indigenous Workers, and Lower Class Clients," Ph.D. Dissertation, (Columbia University, 1965).

Handler, Joel F. and Ellen June Hollingsworth. The Deserving Poor, (Chicago: Markham Publishing Company, 1971).

Hoshino, George. "The Public Welfare Worker: Advocate or Adversary," Public Welfare, 29 (January, 1971): 35-41.

Hussmann, Trudy. "Social Worker's Attitudes About Poverty," MSW Practicum, (Portland State University, 1976).

James, Dorothy Buckton. Poverty, Politics, and Change, (New Jersey: Prentice-Ha11, Inc., 1972).

Kahn, Alfred J. Social Policy and Social Services, (New York: Random House, 1973).

Leonard, Peter. "Towards a Paradigm for Radical Practice," in Roy Baily and Mike Brake, eds., Radical Social Work, (New York: Pantheon Books, 1975): 46-61.

Osgood, Mary H. "Rural and Urban Attitudes Toward Welfare," Social Work, 22 (January, 1977): 41-47. 
Parker, Patricia A. "The Impact of SSI on the Social Security Administration: An Intraorganizational Study with Interorganizational Ramifications," MSW Practicum, (Portland State University, 1976).

Patino, Douglas Xavier. "Relationship Between Attitudes of Professionals and Paraprofessionals Working With Low Income Consumers," Ph.D. Dissertation, (United States International University, 1972).

Patti, Rino J. "Limitations and Prospects of Internal Advocacy," Social Casework, 55 (November, 1974): 537-545.

Pollack, Otto. "American Social Values and Social Welfare," International Social Work, 10 (July, 1967): 31-36.

Roark, Dale 0. "A Survey of Social Studies Teacher's Attitudes Toward Poverty and Welfare Programs in Oklahoma," Ph.D. Dissertation, (Oklahoma State University, 1973).

Ryan, William. Blaming the Victim, (New York: Vintage Books, 1971).

Schiltz, Michael E. Public Attitudes Toward Social Security 1935 1965, Research Report No. 33, (Washington, D.C.: U.S. Government Printing Office, 1970).

SMSA Guidelines, U.S. Bureau of the Census, County and City Data Book, 1972, (A Statistical Abstract Supplement), U.S. Government Printing Office, Washington, D.C.: 1973.

Summers, Gene F. Before Industrialization: A Rural Social System Base Study, College of Agriculture Bulletin 736, (Urbana: University of IITinois, 1969).

Titmuss, Richard M. Commitment to Welfare, (London: George Allen and Unwin Ltd., 1968).

Warren, Roland. "The Sociology of Knowledge and the Problems of the Inner Cities," Social Science Quarterly, 52 (December, 1971): 469-492.

Wassermann, Harry. "Early Careers of Professional Social Workers in a Publ ic Child Welfare Agency," Social Work, 15 (July, 1970): 93-101.

Weaver, Edward T. "Public Assistance and SSI," in NASW Encyclopedia of Social Work Vol. 2 (Albany, New York: Boyd Printing Company, Inc., 1977): 1121-1135.

Williams, Walter. "The Supplemental Security Income Program: Potentially the Next Crucial Step Toward Social Security and Welfare Reform," Public Paper No. 5, Institute of Government Research, University of Washington, January, 1973. 
Williamson, John B. "Beliefs About the Motivation of the Poor and Attitudes Toward Poverty Policy," Social Problems, 21 (June, 1974): 634-648.

- "Beliefs About the Welfare Poor," Sociology and Social Research, 58 (January, 1974): 163-175.

Wooster, John H. "Attitudes Toward Poverty, Social Services, and Adherence to the Protestant Ethic in a Rural Colorado Community," Ph.D. Dissertation, (University of Northern Colorado, 1972).

Wyers, Norman L. Belief, Policy, and Program: Changing Perspectives in America, (Portland State University: Unpublished paper, 1977).

- Line Worker's Attitudes: 01d Paradigms Revisited, (Portland State University: Unpublished paper, 1978). . "On the Effect of Stigma and Other Deterrents on Three Rural Means Tested Programs," DSW Dissertation, (Columbia University: 1975). 


\section{APPENDIX A}

\section{POVERTY: ITS CAUSES AND ITS ERADICATION}

The purpose of this questionnaire is to determine, as you understand them, the causes of poverty, what effective anti-poverty programs should be like, and what an effective worker could do to combat poverty. The study is being sponsored by faculty and students of the School of Social Work, Portland State University. All of the data collected will be treated confidentially, and names will not be used.

We would appreciate your completing this questionnaire. Your answers will be studied along with the answers of several hundred others in this State who do similar work. When this analysis has been completed, we will have a general idea of how people in your roles throughout Oregon percelve poverty, the role of workers, and which programatic strategies are preferred.

Thank you for your participation.

\section{PERSONAL BACKGROUND}

Sex: Male Female

Age: _years)

Highest Academic Degree or Diploma:

Where Obtained:

Year Obtained:

Major:

Years Involved in Programs Working with Poor People:

Years Involved with Present Position:

What is/was Father's Occupation:

Father's Highest Educational Attainment:

What is/was Mother's Occupation:

Mother's Highest Educational Attainment: 


\section{AGENCY INFORMATION}

County there Located:

Number of Persons in Your Caseload: (actual count)

Number of Persons You Provide Services for per Month: (actual count)

Your Job Title:

Job Title of Your Supervisor:

Major Program Area in Which You Work:

Public Assistance

Social Security

Supplemental Security Income

Food Stamps

Other:

Although the above Information about you and your role in the agency is important, your personal attitudes and beliefs about poverty and about poor people in general are of equal interest. Of particular importance are your own personal views about the causes of poverty, the types of programs needed to combat it, and the kinds of services which should be offered to poor people.

Let's take each of these one by one.

\section{PART I}

Following is an attitude scale ranging from 1 through 10 . It is intended to measure how the causes of poverty are at least partially explained by the statement. Notice that a 1 means that you feel that all the causes of poverty can be explained by the statement while a 9 means that you. feel that no amount of poverty can be explained by the statement. Please also note that you may give a 10 response if you are undecided or don't know for certain how you feel. You may indicate your choice by selecting the appropriate number and placing it just below the question itself. 
ON THE CAUSES OF POVERTY

Anount of Poverty Explained by the Statement

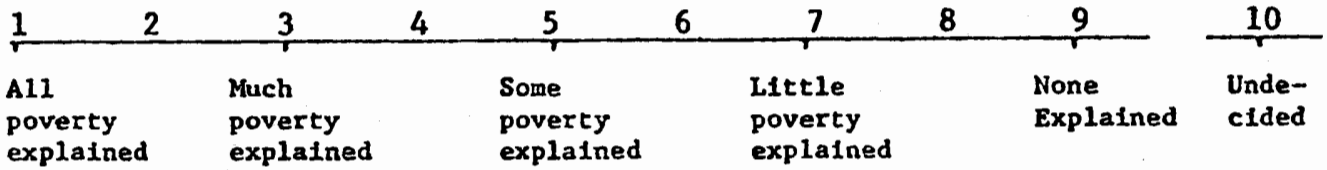

1. Biological factors such as low native intelligence and mental impairment play an important part in causing poverty.

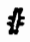

2. Breakdowns in the attainment of goals by the school, the neighborhood, and the local community are the primary causes of poverty.

\#

3. Many families fail to instill values related to self-help and personal motivation in their children or fail to live up to such values themselves, thus giving birth to or condoning poverty.

\#

4. The dynamics of our capitalist economy cause poverty; thus, significant numbers of people end up being poor through no fault of their own.

非

5. The immediate environment of many poor people, including the attitudes of their friends and neighbors, is such that poverty is supported or encouraged.

\#

6. Many low-income people are without sufficient management or budgeting skills, deficiencies which tend. to keep them in poverty.

\#.

7. The lack of education renders many individuals incapable of successfully competing in the job market, making them dependent upon society.

\# 
8. There are not enough jobs to go around.

非

9. The welfare system which we have created is at fault. It is generous and lax to the extent that it encourages laziness and idleness on the part of recipients.

非

10. Our economic system depends in part on the availability of a low-income labor market.

\#

11. Many low-income individuals want to participate in the job market, but are blocked by the market itself.

\#

12. Many poor people deemed by society to be employable in reality don't want to work.

$\#$

\section{PART II}

Here is another attitude scale. Note that a 1 on this scale means that you wholeheartedly endorse the statement, while a 9 means that you do not endorse the statement.

ON PROGRAMS TO FIGHT POVERTY

Program Effectiveness

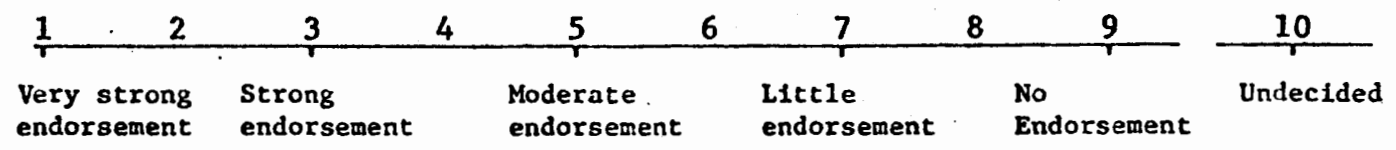

1. To a considerable extent,' anti-poverty efforts would best be accomplished if policies were adopted that abolished work requirements, means-tests, and ellgibility requirements and simply provided poor people with cash transfers ample to maintain a level of living consonant with American standards.

\# 
2. In order to make a large dent in the poverty problem, we should apply counseling and therapy techniques even more than we do now to individuals and their families in order to help them become independent.

非

3. In order to reduce the poverty problem, we should develop programs that would mobilize the whole community in the fight against poverty.

非

4. Many poor people are so dependent or unmotivated that little can be done to change them. We should spend few of our resources on them.

\#

5. The benefit levels to recipients of our social welfare programs should be increased.

非

6. More quality or fxaud control is one means by which our programs could be improved. There are too many people who are cheating the system.

非

7. We should assist poor people to better understand themselves. In this way, they might become better motivated to take care of themselves financialiy.

非

8. All people should be guaranteed a substantial annual income with no qualifications to its receipt.

非

9. Social welfare programs should be expanded. If more benefits were available, there would be less poverty.

非

10. If every person who wanted to work was guaranteed a job, poverty could be significantly reduced.

\# 
11. Proper education would help children of poor families break out of the cycle of poverty.

非

12. Work training programs should be integral parts of public assistance programs as a requirement. Job training would provide more motivation for self-maintenance.

\#

PART III

ON WORKING WITH POOR PEOPLE

Effectiveness of Workers

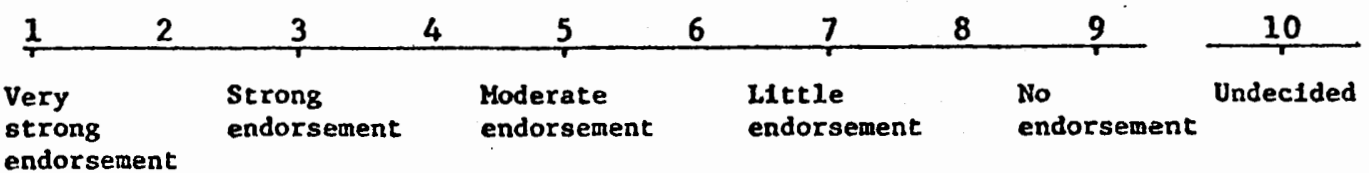

1. The principal efforts of workers should be to help poor people gain psychological insights into the causes of their poverty.

\#⿰

2. Workers should use advocacy techniques extensively in order to make organizations such as schools, social agencies, and employ- ment services more receptive to the needs of poor people.

非

3. Those working with the poor would best help then by involving themselves wholeheartedly in political activities aimed at producing a more equitable society.

\#

4. Those workers who insist that poor people meet their obligations to society through work requirements are on the right track.

非

5. Workers should spend at least a part of their working time helping clients understand that they are being victimized by our economic system.

\# 
6. If poor people could change their immoral/illegal behavior. they would not be as looked down upon by the rest of society. The changing of such behavior is an important goal for them.

非

7. It is imperative for workers in their professional role to work toward the changing of the rules and regulations of this agency so that its tendencies to assist recipients can be strengthened.

\#

8. It is important that workers be supportive and understanding of the people they work with. Clients need to be encouraged.

非

9. Workers should help clients develop better budget and personal management skills since much poverty is caused by poor money management.

A

10. Workers should advocate for clients' rights, even though there may be conflict between those rights and agency policy.

\#

11. Poor people should be encouraged to acquire the necessary educational and work skills which would enable them to better support themselves.

非

12. Workers should legitimately participate in the political organtzing of clients.

\#

PART IV

Please select one or more of the following possibilities as they relate to or describe your educational background and goals.

1. My educational background:

Prepared me adequately to meet the demands of my present role in this agency. 
Was an assist in preparing me to adequately meet the demands of my present role in this agency.

Helped very little in preparing me to adequately meet the demands of my present role in this agency.

Was of no value at all in preparing me to adequately meet the demands of my present role in this agency.

None of the above.

2. If I were to obtain additional education that would help me in my present role in this agency, I would turn toward:

\section{_ Sociology}

Psychology

Public Administration Economics

Social Work

Other:
_Counseling Religion Business Administration Political Science Philosophy

3. I believe that I am most deficient in understanding (select one or more):

The psychology of individual people

The theories of small groups and their impact on people The theories of organizations and their impact on people The dynamics of societies and their impact on people Social stratification Income and wealth distribution in the United States Theories about poverty Individual differences among people Psychopathology Prejudice and discrimination A historical/philosophical analysis of poverty and society's response 
4. The likelihood of my obtaining additional education and/or a hIgher degree is:

Great

Probable
Not likely
Non-existent

Unknown

Other: 


\section{APPENDIX B}

July 15, 1977

Charles Schmutz, Manager

Bend Branch AFS

P. 0. Box 271

Bend, Oregon 97701

Dear Mr. Schmutz:

I am conducting a statewide study of the attitudes of Adult and Family Services, Food Stamps, SSA, and SSI workers about the causes and eradication of poverty and working with the poor. Your agency has been included in the study sample. This study is related to a similar study conducted earlier by me into the same attitudes of administrators.

Portland State University has authorized a grant to complete this study, and we have notified Linda Kaeser about it as well.

In order to obtain valid results in this study, it is important that we interview all of the W.A.W. and Social Service Workers in your agency. I realize that the summer months may be a difficult time to interview everyone because of vacation schedules, but the interviewing must be completed by August 31 . The interview, which may be administered to a number of persons at the same time, is short and will take a maximum of one half hour to complete. Possibly a good time might be just before or after an agency staff meeting.

My colleague, Gene Stutzman, will be in contact with you in the next couple of weeks to arrange an interview time most convenient for you.

Thank you for your cooperation and participation in this study. If you should have any questions at al1, please feel free to call me at 229-4712.

Sincerely,

Dr. Norman L. Wyers 
July 15, 1977

Robert R. Peckham

Branch Manager, SSA

2024 S.W. Fourth Ave.

Ontario, Oregon 97914

Dear Mr. Peckham:

I am conducting a statewide study of the attitudes of Adult and Family Services, Food Stamps, SSA, and SSI workers about the causes and eradication of poverty and working with poor people. Your agency has been included in the study sample. This study is related to a similar study conducted earlier by me into the same attitudes of administrators.

Portland State University has authorized a grant to complete this study, and we have notified Mr. Lee R. Christensen about it as well.

In order to obtain valid results in this study, it is important that we interview all of the Claims Representatives and Service Representatives in your agency. I realize that the summer months may be a difficult time to interview everyone because of vacation schedules, but the interviewing must be completed by August 31. The interview, which may be administered to a number of persons at the same time, is short and will take a maximum of one half hour to complete. Possibly a good time might be just before or after an agency staff meeting.

My colleague, Gene Stutzman, will be in contact with you in the next couple of weeks to arrange an interview time most convenient for you.

Thank you for your cooperation and participation in this study. If you should have any questions at all, please feel free to call me at 229-4712.

Sincerely,

Dr. Norman L. Wyers 